\title{
Timescales from magma mixing to eruption in alkaline volcanism in the Eifel volcanic fields, western Germany
}

\author{
Caren Sundermeyer $^{1} \mathbb{C} \cdot$ Jochen Gätjen $^{1} \cdot$ Lena Weimann $^{1} \cdot$ Gerhard Wörner $^{1}$
}

Received: 13 March 2020 / Accepted: 13 July 2020 / Published online: 25 July 2020

(c) The Author(s) 2020

\begin{abstract}
Diffusion profiles in olivine crystals from the final mafic eruption products of the compositionally zoned Laacher See tephra deposit were measured to identify recharge and eruption-triggering events prior to the eruption of the Laacher See volcano (12.9 kyr). These products represent the hybrids of mixing between phonolite and intruding basanite at the bottom of the reservoir, which is likely related to the eruption-triggering event. Additionally, olivine crystals from ten basanitic scoria cones and maar deposits (East Eifel) and two nephelinites (West Eifel) were analyzed to constrain histories of olivine in Quaternary basanite magmas. Olivine crystals from the Laacher See hybrids vary in core composition $\left(\mathrm{Fo}_{83-89}\right)$ and show reversely zoned mantles with high $\mathrm{Fo}_{87.8-89}$ compared to olivine in East Eifel basanites erupted in nearby, older scoria cones. Towards the crystal margin, olivine in the hybrids develop a normally zoned overgrowth $\left(\mathrm{Fo}_{86.5-87.5}\right)$. Olivine from East Eifel basanites show similar zonation and core compositions $\left(\mathrm{Fo}_{80-88}\right)$ but have less forsteritic mantles $\left(\mathrm{Fo}_{83-88}\right)$ indicating that these basanites are less primitive than those recharging the Laacher See reservoir $\left(>\mathrm{Fo}_{89}\right)$. Olivine in the West Eifel nephelinites show mantles similar to those from Laacher See $\left(\mathrm{Fo}_{87.5-90}\right)$, but have normal zoning and high-Fo cores $\left(\mathrm{Fo}_{88-92}\right)$. This indicates that olivine in the Laacher See hybrids were entrained by a near-primary basanite from older cumulates just before hybridization of the basanite with the phonolite. Diffusion modeling indicates maximum timescales between entrainment and eruption of Laacher See of 30-400 days that are comparable to those calculated for olivine from basanitic scoria cones (10-400 days).
\end{abstract}

Keywords Olivine $\cdot$ Zoning $\cdot$ Timescales $\cdot$ Diffusion $\cdot$ Mixing

\section{Introduction}

The mitigation of potentially violent eruptions of evolved magmatic systems necessitates a better understanding of the pre-eruptive processes such as how fast magmas ascend from deep crustal reservoirs or mantle sources and how fast resident magmatic systems in the crust can be reactivated and triggered to erupt. Many recent studies focus on linking the chemical evolution of magmatic systems to the related timescales (e.g. Albert et al. 2015, 2016, 2019; Kahl et al.

Communicated by Othmar Müntener.

Electronic supplementary material The online version of this article (https://doi.org/10.1007/s00410-020-01715-y) contains supplementary material, which is available to authorized users.

Caren Sundermeyer

csunder@gwdg.de

1 Geowissenschaftliches Zentrum, Georg-August Universität, Göttingen, Germany
2011, 2013; Viccaro et al. 2016; Rasmussen et al. 2018; Ubide and Kamber 2018). Such studies have shown that the interaction of ascending mafic magmas with more evolved melts and crystal mush are a common process in many volcanic systems (e.g. Sparks et al. 1977; Hildreth 1981; Bachmann and Bergantz 2004; Marsh 2006; Hildreth and Wilson 2007). Mafic recharges and subsequent magma mixing may, therefore, be major factors in destabilizing magmatic systems and potentially triggering eruptions (e.g. Sparks et al. 1977; Murphy et al. 2000; Eichelberger et al. 2006; Wark et al. 2007; Ruprecht and Plank 2013; Cashman and Giordano 2014). Processes that may lead up to eruption are preserved in chemically zoned crystals, either in phenocrysts from the recharging magmas or antecrysts disaggregated from older crystal mush. Crystal zoning provides information about chemical compositions of the interacting magmas and the timescales between this interaction and eruption. After the entrainment by a foreign magma, the crystals start to homogenize with the new composition to reach equilibrium. This homogenization will endure until (1) the crystal 
is completely re-equilibrated or (2) the process is interrupted by cooling (e.g. eruption). If homogenization remains incomplete, the compositional gradient between crystal core and rim (in equilibrium with the new melt) can be modeled to constrain the timescales of diffusion and to track the relative periods of time between distinct magmatic events such as magma mixing and eruption (e.g. Costa and Dungan 2005; Cooper and Kent 2014; Lynn et al. 2018). Compositional gradients also allow to reconstruct the temperature history of crystals with known residence time (Rubin et al. 2017; Rout and Wörner 2018). Diffusion of major elements $(\mathrm{Mg}-\mathrm{Fe})$ and trace elements (e.g. Ni) in olivine occurs in the range of hours to years and is, therefore, useful to identify processes as magma ascent (Gordeychik et al. 2018; Mutch et al. 2019), crystal mush reactivation (Bradshaw et al. 2018) and mixing processes (Kahl et al. 2011, 2013; Albert et al. 2015, 2016, 2019; Sundermeyer et al. 2020) that are directly connected to eruptions.

Ascending magmas often interact and mix with older, resident and more evolved magmas and disaggregate older, but cognate crystal-rich mushes that are stored at shallower levels (e.g. Cooper et al. 2016). Recent studies show that mixing and eruption in basaltic magma systems can occur within days to months (e.g. Viccaro et al. 2016; Brenna et al. 2018; Lynn et al. 2018; Albert et al. 2019; Sundermeyer et al. 2020). Even large and compositionally evolved, silicic systems may also yield timescales of only a few years between recharge events and eruption, which is an exceedingly short time for reactivation of these long-lived systems (Cooper and Kent 2014; Cooper et al. 2016; Druitt et al. 2012, 2016).

In this study, diffusion times of olivine crystals from the phonolitic Laacher See volcano in the East Eifel volcanic field (western Germany) are calculated to track the timing of pre-eruptive processes and the final recharge event in a phonolitic magma chamber prior to eruption. We find that the olivine crystals analyzed here are antecrysts entrained from a basanitic crystal mush during ascent but prior to recharge of, and mixing with the resident phonolite magma. Major $(\mathrm{Mg}-\mathrm{Fe})$ and trace elements $(\mathrm{Mn}, \mathrm{Ca}, \mathrm{Ni})$ were chosen to model residence times in the hybrid phonolite + basanite mingled/mixed magmas that formed at the bottom of the magma chamber within the upper crust (Wörner and Wright 1984). Furthermore, in order to constrain ascent rates of such basanite magmas from deep to shallow reservoirs, olivine crystals from basanitic scoria cones of the East Eifel and, for comparison, nephelinitic maar deposits of the West Eifel, were also analyzed to determine their magmatic history before eruption and, by analogy, with respect to mixing with the phonolite magma reservoir at Laacher See volcano.

\section{Geological setting}

\section{Eifel volcanic field}

The Quaternary Eifel intra-plate alkaline volcanic fields are located in the Rhenish Massif, western Germany. The Eifel belongs to the Central European Volcanic Zone, a belt of Cenozoic volcanic centers that extend in SW-NE direction from the Massif Central and the Rhine Graben towards the Rhenish Massif and to the Eger Graben volcanism in the east (Michon and Merle 2001; Nowell et al. 2006). In the Eifel, an older phase of volcanism occurred at 44-40/38-34 Ma in the Hocheifel (Fekiacova et al. 2003; Jung et al. 2006), where alkaline magmas such as basanites, nephelinites, and alkali basalts were erupted (Jung et al. 2006). A younger phase of volcanic activity took place during the Quaternary and can be related to a thermal anomaly of $150-200{ }^{\circ} \mathrm{C}$ higher than ambient temperatures in the asthenospheric mantle (Mertes and Schmincke 1985; Ritter et al. 2001; Nowell et al. 2006). The Quaternary West Eifel volcanic field (WEVF; Fig. 1a) consists of 240 eruptive centers, mostly scoria cones and maars (Duda and Schmincke 1985; Mertes and Schmincke 1985) dated from 0.7 to $0.01 \mathrm{Ma}$ (Mertes and Schmincke 1985). Volcanism in the East Eifel volcanic field EEVF started at $0.46 \mathrm{Ma}$ and culminated in the $12.9 \mathrm{kyr}$ eruption of the Laacher See volcano (Schmincke 2007). The most recent eruption occurred at Ulmener Maar at 11 kyr BP (Schmincke 2007). West Eifel volcanic products are dominated by high-K magmas such as leucitite, nephelinite and basanite (Mertes and Schmincke 1985). The East Eifel is subdivided into the older Rieden center ( 460-430 kyr; Schmincke 2007) that produced phonolitic, leucititic and nephelinitic magmas and a younger, south-eastern part (starting at 215-190 kyr at Wehr volcano, Wörner et al. 1988; Schmincke 2007) that is dominated by basanitic and tephritic scoria cones and maars (Duda and Schmincke 1978, 1985; Bednarz and Schmincke 1990; Schmincke 2007). More evolved magmas were erupted at three main locations: Rieden (phonolitic; Schmincke 2007), Wehr (phonolitic and trachytic; Wörner et al. 1988), and Laacher See (phonolitic; Wörner and Schmincke 1984a, b).

\section{Laacher See volcano-chemical evolution and eruption}

Laacher See volcano is located in the center of the East Eifel volcanic field to the west of the Neuwied Basin (van den Bogaard and Schmincke 1984; Schmincke et al. 1999; Schmincke 2007). The magmatic reservoir of Laacher 
Fig. 1 a Map of the Eifel Volcanic Fields [redrawn and modified after Mertes (1983)]. Black dots show eruptive centers, red dots mark centers with sample locations. b Stratigraphy of the Laacher See Tephra [modified after Ginibre et al. (2004)]. The samples studied here are mafic hybrid clasts at the top of the ULST that represent the final products in the eruption sequence (red box). Inset shows the location of the volcanic fields in relation to the uplifted Rhenish Shield and the Upper and Lower Rhine Graben (URG, LRG)

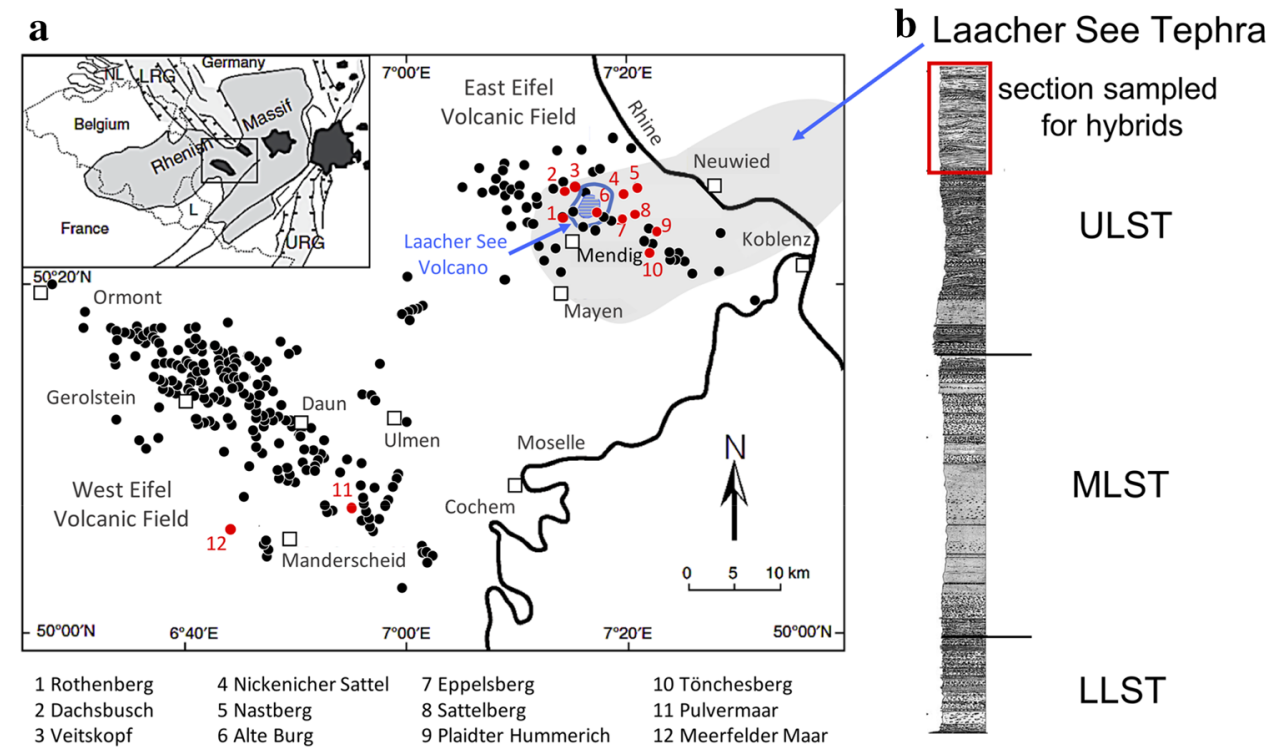

See consists of a magma chamber with its top located at $\sim 3-6 \mathrm{~km}$ depth as indicated by pressure estimates based on experimental phase equilibria (Berndt et al. 2001; Harms et al. 2004; Wörner 1982; Wörner and Schmincke 1984b) and xenolith evidence (Wörner et al. 1982; van den Bogaard and Schmincke 1984). The magma chamber is interpreted to be embedded in cumulates (Tait et al. 1989) and a carapace of cogenetic syenitic rocks that contain interstitial phonolitic melt (Rout and Wörner 2018). This magmatic system is emplaced within sedimentary country rocks of the Lower Devonian and reaches down to phyllites and metamorphic schists (Wörner et al. 1982; van den Bogaard and Schmincke 1984).

The eruption of Laacher See occurred $12.880 \pm 0.040 \mathrm{kyr}$ BP [tephra in varved lake sequences, e.g. (Brauer et al. 1999; Lane et al. 2015; Bronk Ramsey et al. 2015)], an age that overlaps with a ${ }^{14} \mathrm{C}$ age of $12.934 \pm 0.165 \mathrm{kyr}$ BP (Baales et al. 2002). Within days to weeks, the volcano released about $6.3 \mathrm{~km}^{3}$ (DRE) of volcanic products (van den Bogaard and Schmincke 1985; Schmincke et al. 1999). It was the largest eruption in Europe during the late Quaternary and dispersed over $20 \mathrm{~km}^{3}$ of pumice and ash over $>230000 \mathrm{~km}^{2}$ of central Europe (van den Bogaard and Schmincke 1985; Baales et al. 2002; Engels et al. 2015). The Laacher See tephra (LST) was deposited to the east-northeast, south and, at the very end of the eruption, south to west of the volcano (van den Bogaard and Schmincke 1985; van den Bogaard 1995) and has caused damming of the Rhine river and the ephemeral formation of a large lake (Park and Schmincke 1997, 2020; Schmincke et al. 1999). Evolution and structure of the magmatic reservoir are well constrained by studies on the erupted volcanic products (Wörner and Schmincke 1984a, b; Wörner and Wright 1984; Wörner et al. 1985;
Tait et al. 1989; Bourdon et al. 1994; van den Bogaard 1995; Harms and Schmincke 2000; Berndt et al. 2001; Ginibre et al. 2004; Schmitt 2006; Schmitt et al. 2010; Rout and Wörner 2018). The compositionally and texturally stratified LST deposits as described by Wörner and Schmincke (1984a) are subdivided into three main units: Lower, Middle, and Upper Laacher See tephra [LLST, MLST, and ULST, based on Schmincke (1977); Fig. 1b]. The LLST and MLST are characterized by highly evolved and crystal-poor $(<10 \%)$ phonolite. Towards the top of the deposit, as the eruption proceeded, crystal content increases to up to $>50 \%$ in the uppermost layers. Simultaneously, magmatic compositions become less evolved with time during the eruption towards a more mafic phonolite at the uppermost ULST. These observations indicate that the LST represents the content of an inversely erupted, chemically zoned magma chamber. Mass balance arguments based on major and trace element modeling of magmatic differentiation suggest that the $\sim 6 \mathrm{~km}^{3}$ of zoned phonolite magma formed from about ten times the volume of parent basanite by crystal fractionation (Wörner and Schmincke 1984a, b). The formation times of the Laacher See phonolite are still discussed. Bourdon et al. (1994), based on U-Th disequilibria, document a two-step formation over a period of $\sim 100 \mathrm{kyr}$ by differentiation from an originally primitive basanite to mafic phonolite and additional 10-20 kyr towards a more evolved phonolite after emplacement in the shallow crust. The chemical zonation within the phonolite magma reservoir formed likely as a result of convective fractionation within the differentiating magma body, as evidenced from studies on the composition of cumulate nodules (Tait et al. 1989) and zoned sanidine (Ginibre et al. 2004). The timescales necessary to produce the compositional layering are within a range of 
$\sim 3 \mathrm{kyr}$ (Tait et al. 1989) which is largely consistent with the 10-20 kyr of total residence time for phonolite magmas in the Laacher See magma system (Bourdon et al. 1994; Schmitt 2006; Schmitt et al. 2010).

The eruption of crystal-rich mafic phonolite towards the top of the ULST represents the lower parts of the magma chamber. The final erupted products are compositionally heterogeneous mafic clasts with a disequilibrium mineralogy of olivine, Mg-rich clinopyroxene megacrysts, phlogopite, and the entire range of phenocrysts also observed in the crystal-rich phonolite, including zoned sanidine (Rout and Wörner 2020). These hybrids are interpreted to have formed by mixing and mingling between phonolite magma, cumulate minerals, and an intruding basanite (Wörner and Schmincke 1984a, b; Wörner and Wright 1984, Wörner et al. 1985). The event of basanitic recharge was suggested to have been immediately prior to the eruption, as indicated by the incomplete mixing and the occurrence of hybrid magmas only in the lowermost part of the reservoir and thin post-mixing overgrowths on resorbed basanitic clinopyroxene crystals (Wörner and Wright 1984). These authors interpret the mixing, therefore, as a result rather than the trigger of eruption. As we will see from this and a companion study (Wörner and Rout 2020), we can now provide more detailed information on the timing of mixing and eruption during the final stages of magma evolution at Laacher See volcano and its eruption trigger.

\section{Samples and analytical methods}

\section{Sample description}

This study focuses on olivine in samples from the most mafic hybrid products (phonolite + basanite) from the uppermost part of the Laacher See tephra deposit (Fig. 1a, b) in order to constrain the time scale of mixing/mingling to eruption of the phonolite magma reservoir. The analyzed material comprises 47 olivine crystals from nine samples from the mafic hybrids of the ULST. To further constrain ascent times for such mafic magmas from deep (upper mantle/lower crustal) levels towards the shallow crust and to the surface, 21 samples from ten basanitic scoria cones and maar deposits in the East Eifel (Alte Burg $=\mathrm{AB}$, Dachsbusch $=$ HDA, Eppelsberg $=\mathrm{EPB}$, Nastberg $=$ NAS, Nickenicher Sattel $=$ NISA, Plaidter Hummerich $=$ PLH, Rothenberg $=$ E41, Sattelberg $=$ SAT, Tönchesberg $=$ TÖN, and Veitskopf $=$ VEI), and five samples from two locations in the West Eifel (Meerfelder Maar at Deudesfeld $=$ DEU, Pulvermaar $=$ PUL) were also analyzed (Fig. 1a).

\section{Laacher See hybrids}

Upper Laacher See hybrid clasts represent samples 1089 to the most mafic 1101-3 with MgO-contents of 1.0 to 6.9 wt\% (whole rock sample numbers and data from Wörner and Schmincke 1984a; Wörner and Wright 1984). The samples were obtained from the last, uppermost section of the ULST (Fig. 1b) and cover (1) relatively homogeneous, relatively mafic pumice clasts, which are similar to ULST phonolites with respect to their mineral content dominated by sanidine and plagioclase, with minor amounts of amphibole, clinopyroxene, phlogopite, magnetite and sphene. However, these samples also contain rare forsterite-rich olivine with Cr-spinel inclusions indicating the hybrid character. More mafic hybrids (2) are less vesicular, often compositionally heterogeneous on a cm scale with crystal-rich schlieren enclosed in dark dense mafic material that contain olivine and clinopyroxene megacrysts (Wörner and Wright, 1984; Wörner and Schmincke 1984a). Olivine occurs as euhedral crystals up to $8 \mathrm{~mm}$ in size, with some showing strong resorption (Fig. 2a). Groundmass olivine $(<50 \mu \mathrm{m})$ are observed in all Laacher See hybrid lava samples and show either resorption similar to the macrocrysts or a reaction corona of clinopyroxene.

\section{Mafic magmas from scoria cones and maar deposits in the East and West Eifel}

Basanite and nephelinite samples include lava and dikes as well as agglutinates from Eppelsberg, Plaidter Hummerich, and Sattelberg scoria cones that cover their eruptive sequence and compositional variations from the base to the last erupted products. The samples are dense $(<10 \mathrm{Vol} . \%$ vesicles, except of PLH-3 with $\sim 20$ Vol.\%) and porphyritic in texture with phenocrysts of zoned clinopyroxene $(<15$ Vol.\%), olivine (up to $5 \mathrm{Vol} . \%$ ) and phlogopite as phenocrysts. Olivine phenocrysts are euhedral to subhedral, but have commonly resorbed outer rims (Fig. 2b). Rare olivinerich mantle-derived xenoliths, partially with a clinopyroxene reaction corona, occur in samples from Rothenberg, Nickenicher Sattel, Sattelberg, and Tönchesberg that were erupted towards the end of activity of these scoria cones. From the West Eifel, we also collected a mafic crystal cumulate and mantle-derived peridotite nodules as well as juvenile melilite-nephelinite clasts from, respectively, the Pulvermaar and Meerfelder Maar tephra deposit (see Mertes and Schmincke 1985; Duda and Schmincke 1985 for bulk lava compositions).

\section{Mineral analyses}

Electron microprobe analyses were performed using the JEOL JXA 8900RL instrument at the Geoscience Center, Georg-August-University, Göttingen. Major ( $\mathrm{Si}, \mathrm{Mg}, \mathrm{Fe}$ ) 


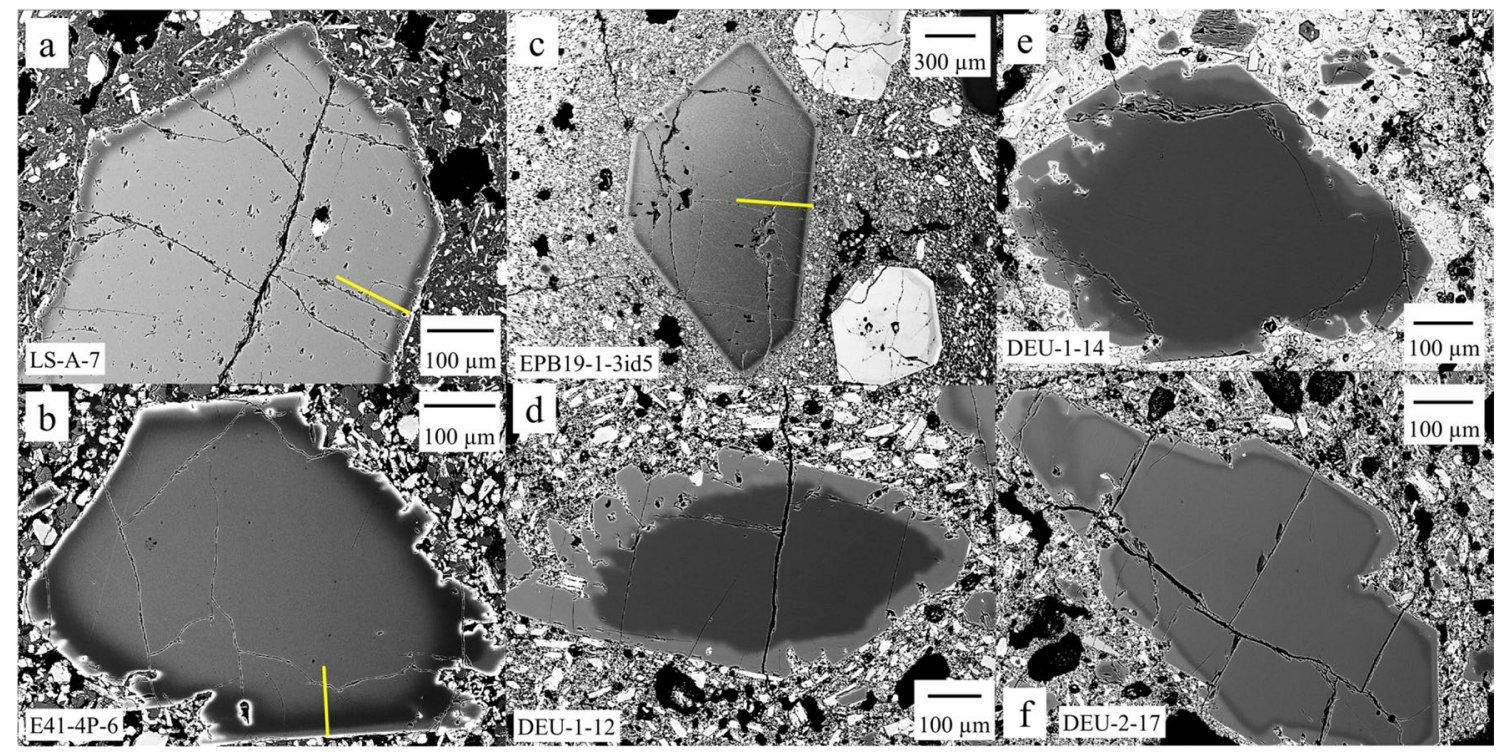

Fig. 2 Back-scattered electron (BSE) images of representative olivine crystals from the samples from Laacher See (a), Rothenberg (b), Eppelsberg (c), and Meerfelder Maar (d-f). Olivine crystals from Laacher See mafic hybrids, Rothenberg, and Eppelsberg show the complex reverse zoning (reverse-normal) that is typical for all olivine

and trace elements ( $\mathrm{P}, \mathrm{Al}, \mathrm{Cr}, \mathrm{Mn}, \mathrm{Ca}, \mathrm{Ni}, \mathrm{Co}$, and $\mathrm{Zn}$ ) were measured at conditions similar to those described in Gordeychik et al. (2018): Counting times were set to $15 / 5 \mathrm{~s}$ for peak/ background of the major elements, $60 / 30 \mathrm{~s}$ for Mn, 120/60 s for $\mathrm{Ca}, \mathrm{Cr}$, and $\mathrm{Zn}, 180 / 90 \mathrm{~s}$ for $\mathrm{Co}, 260 / 130 \mathrm{~s}$ for $\mathrm{Ni}$ and $\mathrm{Al}$, and $300 / 150 \mathrm{~s}$ for P. Accelerating voltage was set to $20 \mathrm{keV}$ with a beam current of $300 \mathrm{nA}$ and a beam focused to $1 \mu \mathrm{m}$. The extended counting times and high beam current result in $2 \sigma$-uncertainties of $<1 \%$ for the major elements, $<2 \%$ for $\mathrm{Ca}, \mathrm{Mn}$, and $\mathrm{Ni}$, and $<4 \%$ for $\mathrm{Al}$. Uncertainties are $9-12 \%$ for Co and 6-10\% for $\mathrm{P}$, but can reach up to $20 \%$ in olivine crystals with $P<0.01 \mathrm{wt} \%$. Zn and $\mathrm{Cr}$ have uncertainties of $10-40 \%$ and $10-70 \%$ due to their low concentration close to the detection limits $(0.006 \mathrm{wt} \%$ and $0.004 \mathrm{wt} \%$, respectively). Reference materials for calibration are San Carlos olivine $(\mathrm{Si}, \mathrm{Mg})$, hematite $(\mathrm{Fe})$, rhodonite $(\mathrm{Mn})$, wollastonite (Ca), $\mathrm{NiO}(\mathrm{Ni})$, anorthite (Al), $\mathrm{ScPO}_{4}(\mathrm{P}), \mathrm{Cr}_{2} \mathrm{O}_{3}(\mathrm{Cr})$, Co metal $(\mathrm{Co})$, and gahnite $(\mathrm{Zn})$. All standards were measured before and after every analytical session, San Carlos olivine and hematite reference materials were additionally analyzed after each line profile measured.

Quantitative line profiles were measured from rim to core (2-5 $\mu \mathrm{m}$ step size) to document chemical zonation in olivine at high spatial and analytical resolution. Additionally, single point analyses were performed on 30 olivine crystals from ULST hybrid clasts, 147 olivine crystals from the East Eifel basanite samples and 82 olivine crystals from West Eifel nephelinite samples. Two to three measurement points were crystals from the East Eifel samples. Yellow lines mark measured line profiles (see Fig. 4a, b). Olivine from Meerfelder Maar samples show the normal-zoned high-Fo cores that are typical for samples from the West Eifel. f Example of reverse-normal zoning trend which occurs rarely in the samples from the West Eifel nephelinites

set on each olivine grain to obtain representative core and rim compositions. Our analyses focus on olivine macrocrysts but include also olivine crystals in the matrix as well as olivine-rich xenoliths. All analytical data is given in Online Resource 1 and 2.

Element distribution maps for $\mathrm{Ni}, \mathrm{Ca}, \mathrm{P}, \mathrm{Al}$, and $\mathrm{Cr}$ were acquired for two zones of one olivine grain $(240 * 240 \mu \mathrm{m}$ and $240 * 416 \mu \mathrm{m}$ ) of a complexly zoned crystal from Eppelsberg basanite (EPB19-1-3id8). Measurement conditions during mapping were $20 \mathrm{keV}$ at high $600 \mathrm{nA}$ to detect trace elements with sufficient precision.

\section{Thermometry and crystal orientation}

Temperature is the major factor that controls elemental diffusion and must be, therefore, carefully constrained for diffusion modeling. Temperatures were calculated based on the Al-in-olivine/spinel-thermometer (Coogan et al. 2014) based on 20 olivine-spinel-pairs in samples from Laacher See Tephra, six in samples from Eppelsberg (EPB), and three in samples from Rothenberg (E41) using the same measurement conditions for olivine as described above. A special analytical set-up was applied to measure spinel inclusions ( $20 \mathrm{keV}, 20 \mathrm{nA}$, a focused beam). Counting times were set to 30/15 s for Ti and $\mathrm{Cr}$, and 15/5 s for $\mathrm{Si}, \mathrm{Al}, \mathrm{V}, \mathrm{Mg}, \mathrm{Fe}$, $\mathrm{Mn}, \mathrm{Ni}, \mathrm{Zn}$. The analyses encompass $\mathrm{Cr}$-spinel inclusions from all compositional zones of olivine crystals. The spinels 
have \#Cr of 0.05-0.50, which match the calibration range of the thermometer $(0<\# \mathrm{Cr}<0.69$; Coogan et al. 2014). The complete dataset is given in Online Resource 3.

Elemental diffusion of $\mathrm{Mg}-\mathrm{Fe}, \mathrm{Mn}$, and $\mathrm{Ni}$ in olivine is strongly anisotropic and can be described as $6 D_{\mathrm{a}}=6 D_{\mathrm{b}}=D_{\mathrm{c}}$ (Dohmen et al. 2003; Costa and Chakraborty 2004) with $D_{\text {a, b, c }}$ as diffusion coefficients along the crystallographic axes. Diffusion modeling, therefore, requires the knowledge of crystal orientation with respect to the direction of the measured profile. For oblique cuts, the orientation of the olivine crystals was determined via EBSD (electron backscatter diffraction; Prior et al. 1999) at the FEI Quanta 200 F scanning electron microscope at the Geoscience Center, Georg-August-University, Göttingen. The thin sections were not coated to avoid signal weakening. 10-15 measurement points were set along the analyzed line profiles to exclude heterogeneities in crystal orientation using a DigiView V camera (EDAX-Ametek) and TSL OIM software for data collection (measurement conditions: $15 \mathrm{keV}, 150 \mu \mathrm{A}$, and $4 \mu \mathrm{m}$ spot size).

\section{Results}

\section{Chemical composition of olivine crystals from Laacher See hybrids}

We distinguish three types of olivine crystals in the hybrid clasts:

1 Olivine macrocrysts in Laacher See hybrids are similar in size and shape to phenocrysts in basanitic samples from scoria cones (see below) and between 100 and $500 \mu \mathrm{m}$ in size. Texturally they are clearly in disequilibrium with the phonolitic minerals (e.g. sanidine, plagioclase, amphibole, sphene) in the mingled rocks. As such, these olivine crystals are xenocrysts to the phonolite but could be phenocrysts with respect to the basanite. Compositionally, these macrocrysts can be divided into three zones (Figs. 3, 4): (a) core compositions that are variable between different crystals $\left(\mathrm{Fo}_{83.1-89.1}\right.$, $\mathrm{NiO}=0.07-0.24 \mathrm{wt} \%$, Figs. 5, 6), (b) a high-Fo mantle $\left(\mathrm{Fo}_{87.8-89}, \mathrm{NiO}=0.15-0.2 \mathrm{wt} \%\right)$, which is rather uniform for all crystals, (c) a thin $(<10 \mu \mathrm{m})$ overgrowth at the outer rims back to $\mathrm{Fo}_{84.7-86.8}$ and $\mathrm{NiO}=0.12-0.15 \mathrm{wt} \%$ (Figs. 3, 4a-c). This results in complex (reverse-normal) zoning forming peculiar "inverse loops" in $\mathrm{Ni}-\mathrm{Fo}$ diagrams (Fig. 5). It is apparent that these olivine crystals must have had a prolonged history during which they

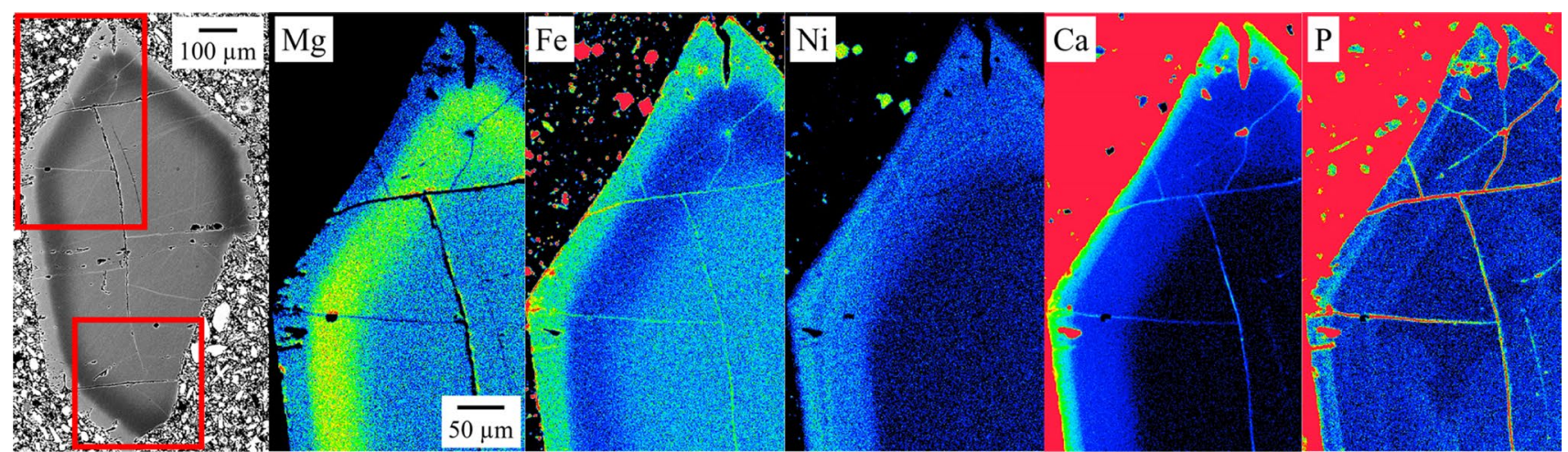

EPB-1-3id8
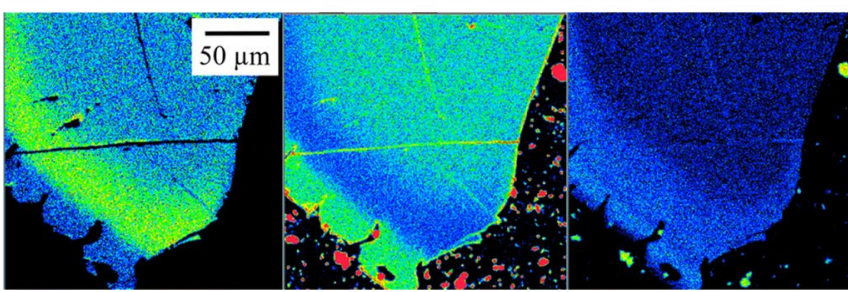

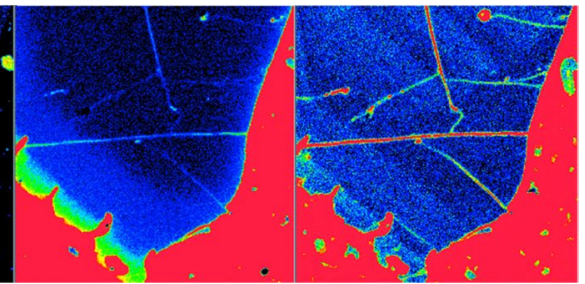

Fig. 3 Backscattered electron image (BSE) showing mass contrasts $($ dark $=\mathrm{Mg}$-rich; bright $=$ Fe-rich $)$ and elemental distribution maps for $\mathrm{Mg}, \mathrm{Fe}, \mathrm{Ni}, \mathrm{Ca}$, and $\mathrm{P}$ in olivine from Eppelsberg (EPB19-1-3-id8). Red squares mark the mapped areas. Element concentrations increase from blue over green to reddish colors. Reverse-normal zonation is clearly visible by the high- $\mathrm{Mg}$ mantle and low-Mg rim. $\mathrm{P}$ is highly concentrated in the mantle and also shows distinct zoning in the olivine core, which is already homogenized in other, more slowly diffusing elements. Note the absence of a compositional gradient where the crystal was fragmented and the fracture surface is now exposed to the host matrix 
Fig. 4 Major and trace element concentrations in selected olivine crystals from a, $\mathbf{d}$ Laacher See, $\mathbf{b}, \mathbf{e}$ Rothenberg, and $\mathbf{c}, \mathbf{f}$ Eppelsberg. For $\mathrm{Fo}, \mathrm{MnO}, \mathrm{CaO}$, and $\mathrm{NiO} 2 \sigma$-uncertainties are within the symbols. Olivine from basanitic samples show at least two additional growth zones in slowly diffusing trace elements $(\mathrm{P}, \mathrm{Al}, \mathrm{Cr})$ at distances of $\sim 40$ and $\sim 100 \mu \mathrm{m}$ from the rim. These growth zones are not visible in major element concentrations due to faster re-equilibration. Such zoning is absent in olivine from Laacher See samples
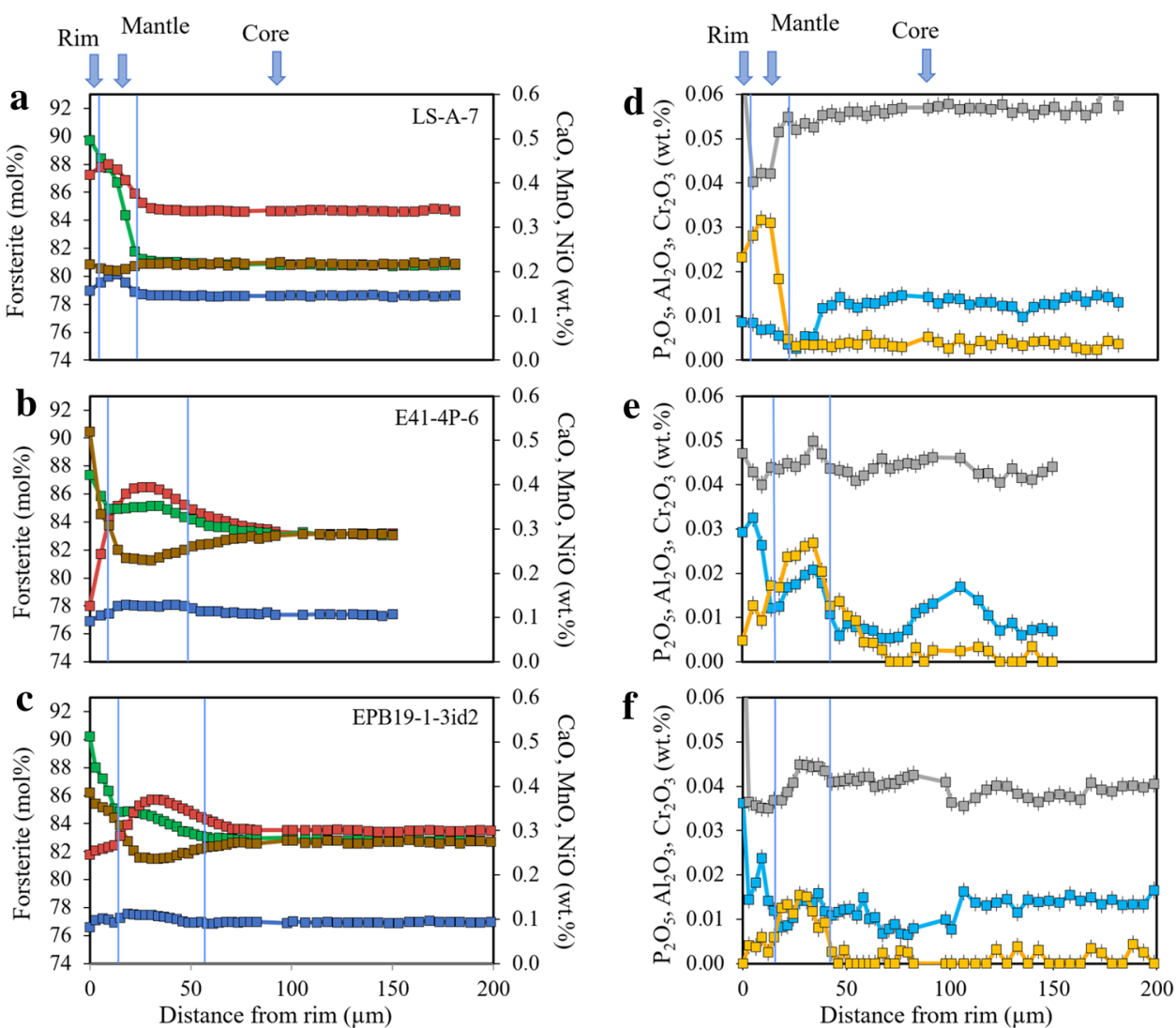

$$
\begin{array}{ll}
\hline-\mathrm{Fo} & -\mathrm{P}_{2} \mathrm{O}_{5} \\
-\mathrm{CaO} & -\mathrm{Al}_{2} \mathrm{O}_{3} \\
-\mathrm{MnO} & -\mathrm{Cr}_{2} \mathrm{O}_{3} \\
-\mathrm{NiO} &
\end{array}
$$

encountered different melt compositions from which they grew and with which they exchanged by diffusion.

2 Olivine megacrysts differ profoundly from the strongly zoned olivine macrocrysts described above: megacrysts are compositionally homogeneous throughout their cores and are only zoned at the outermost $<50 \mu \mathrm{m}$ of the crystals. However, the composition and inverse looped pattern of the outermost zoning are similar to the macrocrysts. Minor and trace elements in general show zoning patterns similar to Fo at the mantles and are unzoned in the olivine cores. The trends of zoning pattern for $\mathrm{NiO}$ differs from those of Fo in several crystals (Fig. 7). Whereas Fo is reversely zoned, $\mathrm{NiO}$ shows normal zonation and a mantle is absent $\left(\mathrm{NiO}_{\text {core }}=0.19-0.23 \mathrm{wt} \%\right)$.

3 Olivine microcrysts $\left(\mathrm{Fo}_{87.4-89.2}, \mathrm{NiO}=0.17-0.2 \mathrm{wt} \%\right)$ are abundant in the matrix of the hybrid clasts, small in size (less than $30 \mu \mathrm{m}$ ) and distinctly more $\mathrm{Mg}$-rich than the outer rims of the cores of olivine crystals described above. However, these smaller crystals are similar in composition $\left(\mathrm{Fo}_{86.3-89.1}, \mathrm{NiO}=0.14-0.2 \mathrm{wt} \%\right)$ to the outer mantles of the macro- and megacrysts described above.

In addition to these types, previous work has identified olivine from xenoliths in Laacher See hybrid samples that were not analyzed in this study. Three types of ol-bearing xenoliths are distinguished: cpx-rich and ol-bearing wehrlites, mantle-derived peridotites, and ol-rich, dense cumulate clasts with olivine compositions of $\mathrm{Fo}_{84-86}$ (Wörner and Schmincke 1984a; Wörner and Wright 1984).

\section{Origin of the different olivine types}

All olivine crystals in Laacher See hybrid lavas are clearly related to a basanite magma that intruded and intermingled with the resident phonolite before eruption. Olivine megacrysts occur together with large $(>1.5 \mathrm{~cm})$ compositionally homogeneous clinopyroxenes and equally homogeneous megacrystic phlogopites $(>1 \mathrm{~cm})$ and, therefore, are likely derived from the same sources. Probably, these megacrysts represent crystal cargo that was picked up by the basanite 


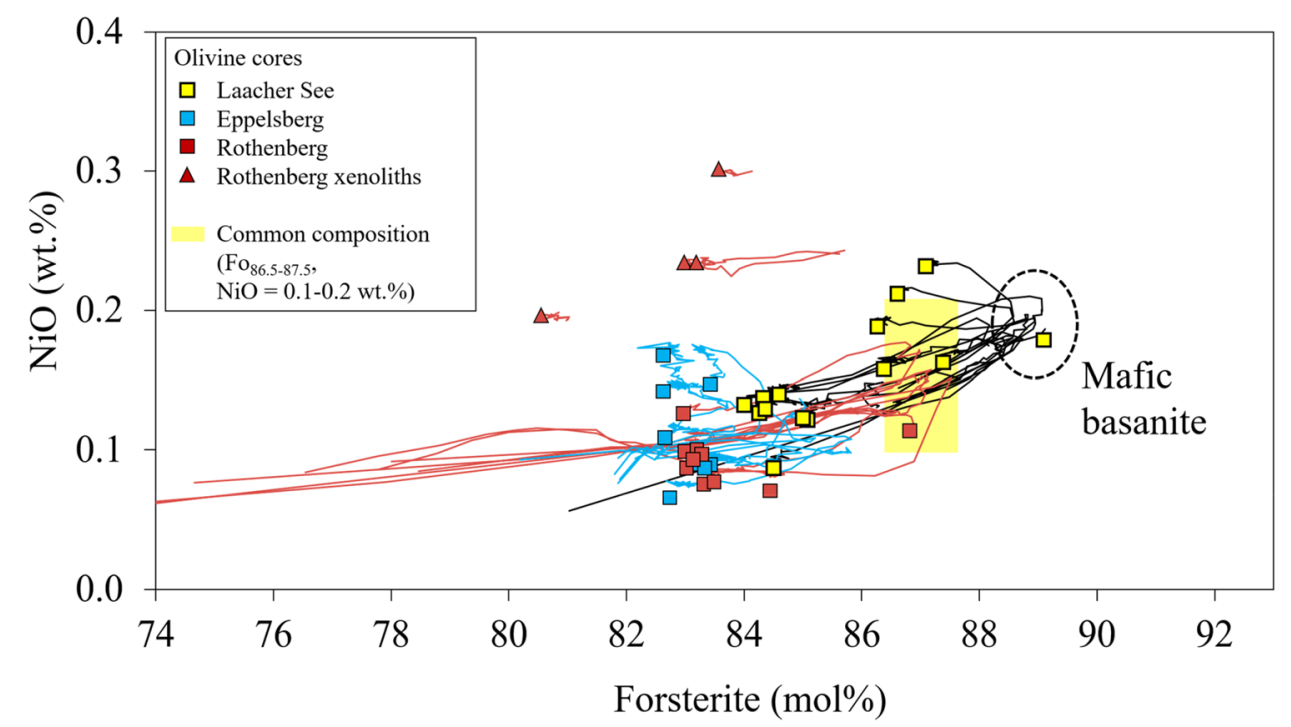

Fig. 5 Measured $\mathrm{NiO}$ and Fo concentrations along line profiles in zoned olivine crystals from Laacher See phonolite, and Rothenberg and Eppelsberg basanite. The lines start at the crystal cores and trace olivine compositions towards forsteritic mantles and then back towards the low-Fo rim. All olivine crystals show this same general pattern of reverse zoning towards a Fo-maximum followed by normal zoning. Olivine cores can be divided into distinct groups based on NiO/Fo distribution along the profile. Several cores (three from Eppelsberg and three from Laacher See) have starting compositions that fall above the general Fo-Ni trend from maximum Fo to the rims.

during ascent from older basanitic intrusive bodies. We note that to our knowledge such homogeneous megacrysts have not been observed in basanites erupted from scoria cones in the East Eifel.

Olivine macrocrysts are considered to represent the phenocrysts of the basanite magma. Their cores and mantle zonation reflect the ascent and compositional history of the basanite before intruding and mingling into the Laacher See phonolite magma. Since the mantles of the macrocrysts and olivine in the matrix are of the same composition, the crystallization of matrix olivine probably occurred contemporarily with the formation of the high-Fo mantle of the macrocrysts. Both also show resorbed crystal shapes. Therefore, we argue that the Fo-rich mantles and the microcrysts olivine must have been formed before the basanite-phonolite mingling event.

This means that the basanite magma intruding into the Laacher See phonolite reservoir prior to its eruption must itself have had a history of mixing and zoned olivine growth before mingling with the crystal-rich mafic phonolite. As we will demonstrate below, this prior history of the Laacher See basanite is distinct from the history of basanite lavas that erupted in nearby scoria cones.
The yellow field identifies the common composition $\mathrm{Fo}_{86.5-87.5}$, which marks the maximum forsterite content in olivine mantles from basanite scoria cones that largely overlaps with zoned olivine from Laacher See hybrids. Olivine mantles in the Eppelsberg samples do not reach the common composition, which may be due to re-equilibration towards lower Fo contents. The region circled by a black dashed line (Mafic basanite) indicates uniform maximum Fo contents in mantles of olivine from Laacher See hybrids that is never observed in basanite samples

\section{Composition of olivine phenocrysts in East Eifel basanites}

The olivine phenocrysts analyzed in samples from the basanitic East Eifel scoria cones that formed during the past c. 100-200 kyr activity close to the Laacher See eruptive center also share a complex-reverse zoning pattern similar, but not identical to those of the olivine crystals from the Laacher See hybrids. A common feature is the homogeneous core at variable Fo and a relatively Fo-richer mantle (Figs. 4, $5,7)$. However, the maximum mantle compositions of phenocrysts in basanites are always below $\mathrm{Fo}_{88}$ and thus never reach the maximum Fo in mantles observed in Laacher See hybrid samples $\left(\mathrm{Fo}_{89}\right)$. One olivine crystal from an Eppelsberg sample shows a zoning pattern for $\mathrm{NiO}$ and Fo distinct from those in the other basanites but similar to the megacrysts from Laacher See hybrids (Fig. 7).

Line profiles of trace elements $(\mathrm{P}, \mathrm{Al})$ in olivine crystals from Rothenberg and Eppelsberg samples also reveal a more complex history with distinct growth zones (Figs. 3; 4e, f). P has a low diffusivity in olivine (Watson et al. 2015) and will, therefore, preserve compositional growth zonation, while $\mathrm{Mg}-\mathrm{Fe}, \mathrm{Mn}$, and Ni will tend to become equilibrated by diffusion (Milman-Barris et al. 2008; Bouvet de Maissonneuve et al. 2016; Gordeychik et al. 2018). Several correlated peaks 
Fig. 6 NiO-Fo diagrams for a cores, $\mathbf{b}$ mantles, and $\mathbf{c}$ rims of all olivine crystals analyzed in this study. Grey and reddish fields mark the measured core compositions from West and East Eifel olivine samples, respectively, as reference in all three diagrams. The green field shows peridotite compositions after Carswell et al. (1979), Simon et al. (2007), and De Hoog et al. (2010). Core compositions of olivine crystals clearly differ between high-Fo compositions for the West Eifel nephelinite and more evolved compositions found in the East Eifel basanite samples. Olivine cores from the Laacher See hybrids largely overlap those from the East Eifel basanites. However, mantle compositions in olivine from hybrids reach to distinctly higher values of up to $\mathrm{Fo}_{89}$. The high-Fo olivine crystals from the nephelinites partially overlap with olivine compositions in peridotites and some may, therefore, originate from disaggregated peridotite xenoliths

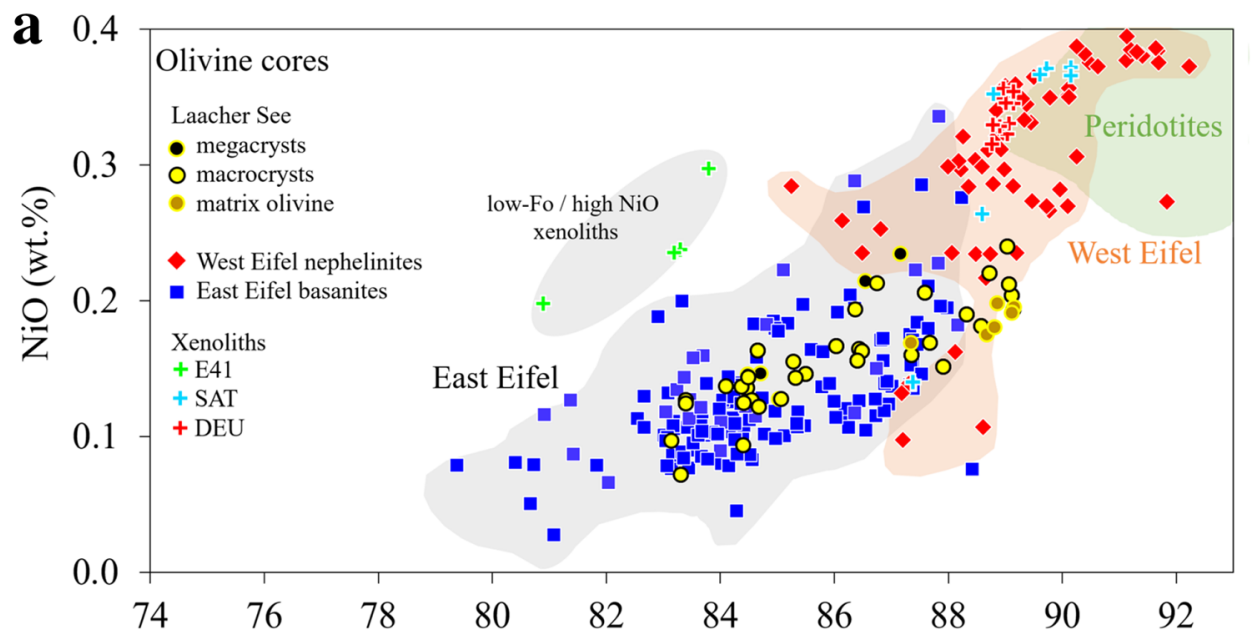

b
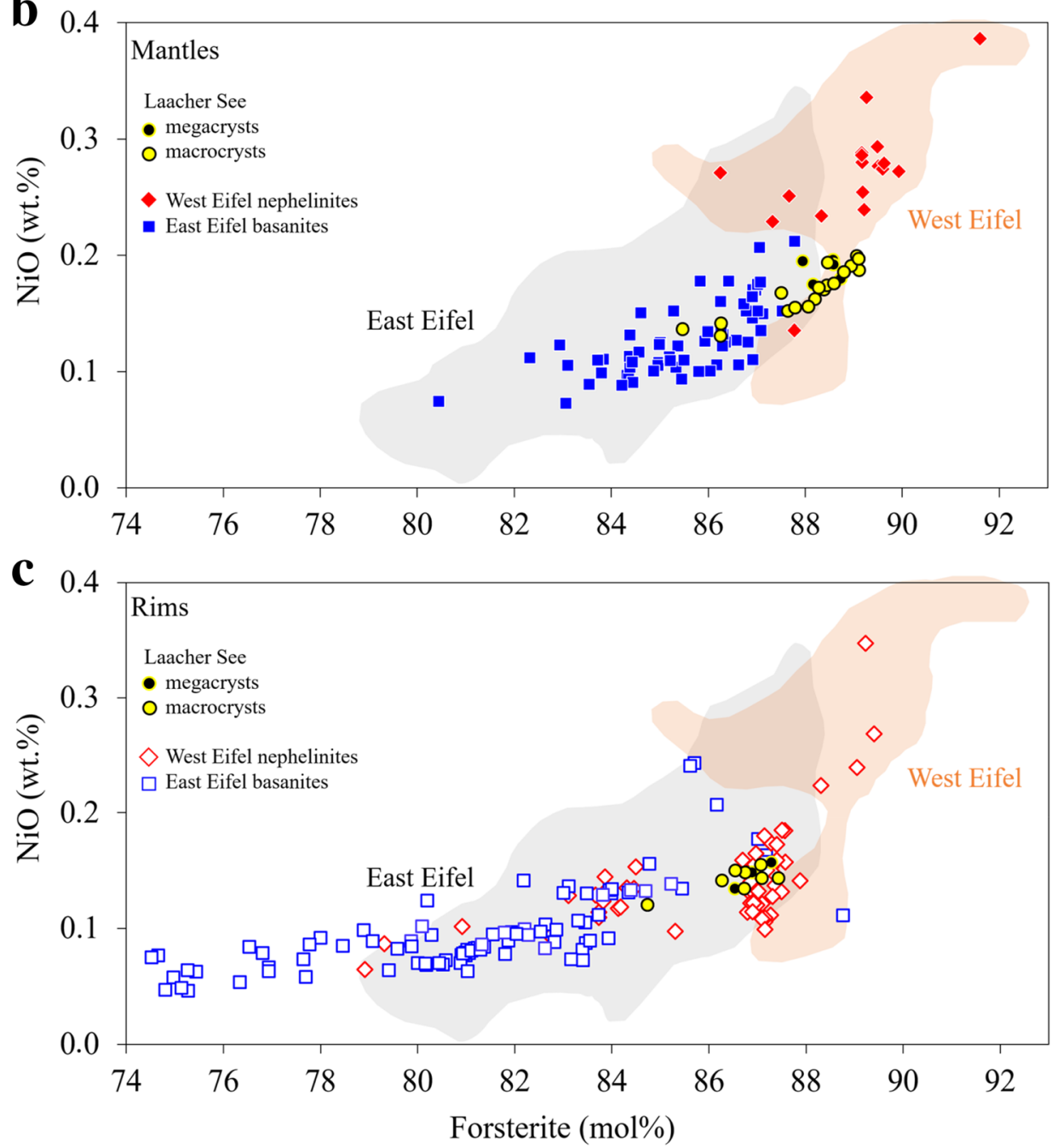

in $\mathrm{P}$ - and $\mathrm{Al}$-contents show at least two distinct growth zones in olivine from the Rothenberg basanite (E41) at $\sim 40 \mu \mathrm{m}$ and $\sim 100 \mu \mathrm{m}$ distance inwards from the rim (Fig. 4e, f).

Olivine core compositions are rather variable and range from $\mathrm{Fo}_{80.7-88.4}$ (Fig. 6a) with compositional variations being similar for all basanites: $\mathrm{Fo}_{82.5-87}(\mathrm{AB}), \mathrm{Fo}_{83-87.2}$ (EPB), $\mathrm{Fo}_{83.1-83.8}$ (E41), $\mathrm{Fo}_{83.7-86.8}$ (HDA), $\mathrm{Fo}_{83.3-86.4}$ (NAS), $\mathrm{Fo}_{84.2-88}$ (NISA), $\mathrm{Fo}_{82.7-88.4}$ (PLH), $\mathrm{Fo}_{80.9-88.2}$ (SAT), $\mathrm{Fo}_{80.7-88.2}(\mathrm{TO} N)$, and $\mathrm{Fo}_{81.1-87.9}(\mathrm{VEI})$. NiO-contents in 

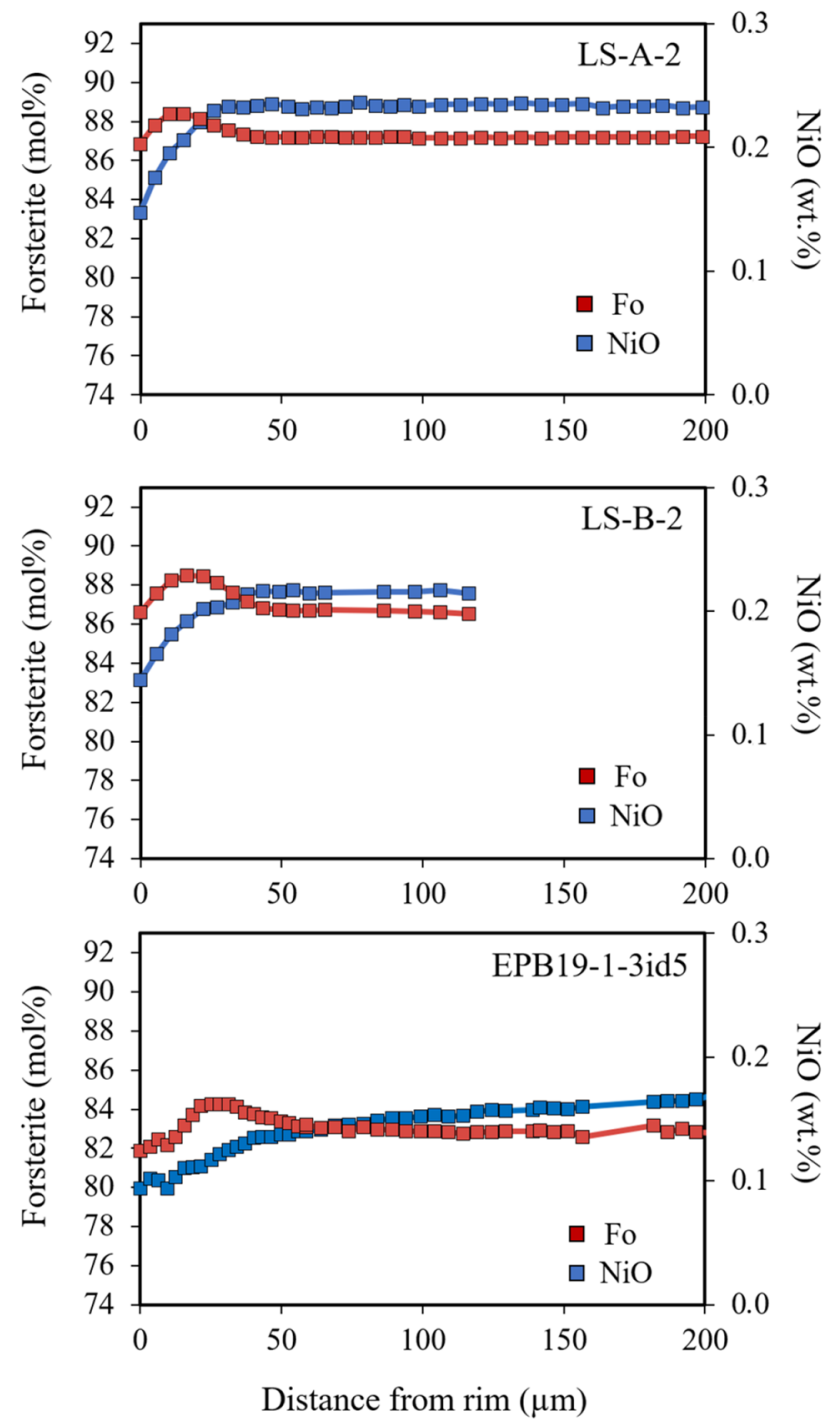

Fig. 7 Rare olivine in Laacher See and Eppelsberg samples show a zoning in $\mathrm{NiO}$, which differs from the Fo zoning pattern and lacks a $\mathrm{NiO}-$ rich mantle. Commonly, element distribution of $\mathrm{NiO}$ along the measured profiles is similar to Fo. Nakamura (1995) and Lynn et al. (2017) interpret this phenomenon as a result of diffusion-triggered zoning due to heating or magma mixing, which affected only the faster diffusing $\mathrm{Mg}-\mathrm{Fe}$

olivine cores are also variable in all basanite samples between $\sim 0.05$ and $0.21 \mathrm{wt} \%$.

Overall, the mantle compositions of olivine crystals from the basanite samples show a range similar to the cores $\left(\mathrm{Fo}_{80.4-87.8}, \mathrm{NiO}=0.07-0.21 \mathrm{wt} \%\right)$, however, the mantles always show higher Fo contents than the core (up to $7 \mathrm{~mol} \%$ Fo). This results in typical "humped" concentration profiles (e.g. Figs. 5, 7) where the core composition and the maximum Fo content is different in each crystal. The higher average Fo contents of the mantles clearly indicate that the maximum is formed by olivine crystals interacting with a basanite magma that is more mafic than the host melt from which the olivine cores have grown. However, the maximum Focontent in the olivine mantles is always significantly lower than those found in Laacher See hybrid lavas (see above).

The large compositional range of olivine mantle compositions indicate that the basanite melts from which they have grown are rather different in composition. An important observation in this context is that the mantles not only differ between samples but also, and to the same extend, within a particular basanite host. This may be unexpected because the mantles should represent equilibrium with a new, more mafic basanitic melt and, therefore, are expected to be similar in olivine from a particular sample.

However, the mantle compositions form a sharp peak and no compositional plateau amenable for diffusion modelling is observed (Fig. $4 a-c$ ). Thus, the peak Fo values may not represent the original equilibrium composition but were already affected by diffusion between mantle and rim. An additional possibility is that resorption of the crystal that has cut to variable depth into the compositional gradient extending from a uniform high-Fo mantle into the uniform core. In both cases, the original mantle Fo-composition would have been overprinted and variably lowered by diffusive equilibration and only the maximum Fo-rich mantle composition $\left(\sim \mathrm{Fo}_{86-88}\right)$ in a sample can be assumed to be close to, and a minimum value for the equilibrium composition of the melt from which the mantles have grown.

Fo-contents towards the outer rims are generally low, but cover a wide range $\left(\mathrm{Fo}_{68.6-87.2} ; \mathrm{Fig}\right.$. 8). This may be partly caused by analytical limitations due to the steep gradients and the narrow zoned rim overgrowth $(<10 \mu \mathrm{m})$, which could not be reliably measured to the very boundary of all crystals (Fig. 6c).

Matrix olivine $(<50 \mu \mathrm{m})$ were analyzed only in basanite samples from Eppelsberg $\left(\mathrm{Fo}_{73.8-79.6}, \mathrm{NiO}=0.04-0.08\right.$ $\mathrm{wt} \%)$. They are even more evolved than the rims of the phenocrysts $\left(\mathrm{Fo}_{79.4-87.2}, \mathrm{NiO}=0.07-0.21 \mathrm{wt} \%\right)$.

\section{Chemical composition of olivine crystals from West Eifel nephelinites}

Olivine phenocrysts from the West Eifel nephelinite samples from Meerfelder Maar and Pulvermaar (DEU, PUL) are dominantly normally zoned with a high-Fo core and a low-Fo mantle (Figs. 2d, 8). Olivine crystals with three compositional zones are also rarely found and show either a normal-normal zoning with a two-step decrease of Focontent towards the mantle or a reverse-normal zoning as observed for olivine crystals from the East Eifel samples (Fig. 2e, f). 
Fig. 8 Boxplots showing the compositional range of olivine cores, mantles, and rims in all samples for easier comparison. Olivine core compositions from East Eifel basanites cover a similar range but are always lower than those from Laacher See hybrids and the West Eifel nephelinites. Maximum mantle compositions of olivine in basanite samples are all more forsteritic than their cores, indicating reverse zoning, and are also less variable in composition than the cores. In the nephelinite samples, olivine mantles are all less forsteritic than their cores. Their outermost rims are in general less forsteritic than cores and mantles, but cover a wide range in each sample. This could, however, be due to the narrow widths of the outermost zone (a few microns) that make measurements analytically difficult

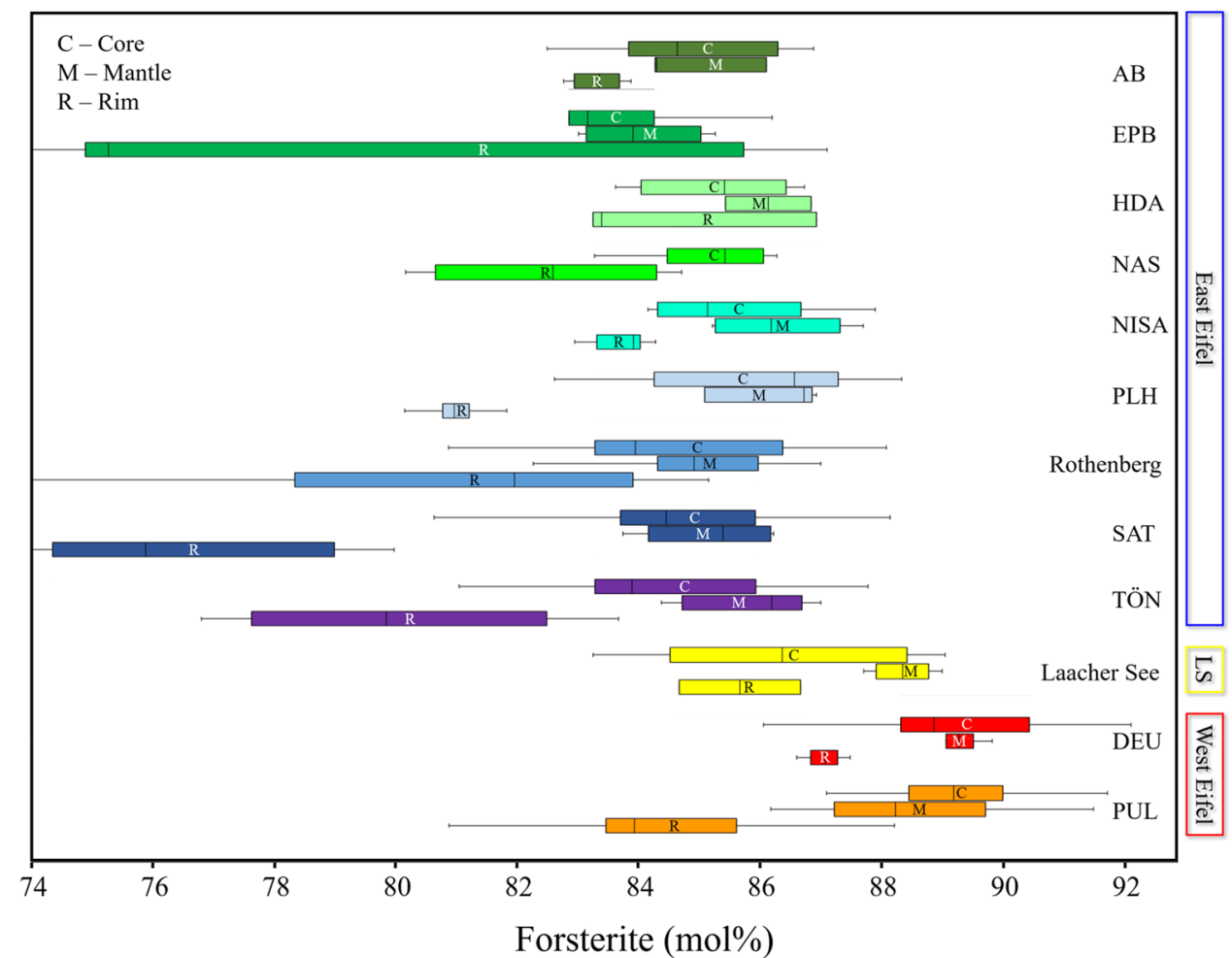

Olivine cores are more primitive with $\mathrm{Fo}_{86.1-92.2}$ (DEU) and $\mathrm{Fo}_{85.2-91.8}$ (PUL) and $\mathrm{NiO}=0.1-0.39$ wt\%. Olivine mantles are less forsteritic with $\mathrm{Fo}_{87.3-89.9}$ (DEU) and $\mathrm{Fo}_{86.3-91.6}$ (PUL).

Matrix olivine were analyzed in DEU $\left(\mathrm{Fo}_{86.5-88.4}\right.$, $\mathrm{NiO}=0.05-0.22 \mathrm{wt} \%)$ and PUL $\left(\mathrm{Fo}_{74.9}, \mathrm{NiO}=0.05 \mathrm{wt} \%\right)$. The compositions of matrix olivine from DEU correlate with the rims of the phenocrysts and are also close to the common composition $\left(\mathrm{Fo}_{86.5-87.5}, \mathrm{NiO}=0.1-0.2 \mathrm{wt} \%\right)$, to which the mantles of all analyzed olivine compositions tend to converge (Figs. 6c, 8). It is notable that this common composition is the same as for the rims of olivine crystals in Laacher See hybrids.

\section{Ol-rich xenoliths}

Small peridotite xenoliths (less than $2 \mathrm{~cm}$ ) rarely occur in basanite samples of the East Eifel but are abundant in more primitive West Eifel nephelinite centers. Analyses were performed on 14 xenolithic olivine crystals from four East Eifel basanite lavas and one West Eifel nephelinite. In the East Eifel, two types were identified based on their composition: (1) one type is low in $\mathrm{Fo}$ and $\mathrm{NiO}\left(\mathrm{Fo}_{79.3-80.9}\right.$, $\mathrm{NiO}=0.11-0.19 \mathrm{wt} \%$; samples NISA and E41), and (2) a high-Fo and high-NiO type $\left(\mathrm{Fo}_{88.6-90.1}, \mathrm{NiO}=0.27-0.38\right.$ wt $\%$; NISA, SAT and TÖN). However, one analysis from SAT matches none of the compositions $\left(\mathrm{Fo}_{87.4}, \mathrm{NiO}=0.14\right.$ wt\%). The distinct high-Fo/high-NiO type can be clearly identified as olivine from mantle peridotites (Fig. 6a). Olivine from the xenoliths found in the Rothenberg basanite dike have low $\mathrm{Fo}_{83-84.1}$, but a high $\mathrm{NiO}=0.23-0.3 \mathrm{wt} \%$. This xenolith shows a 50-100 $\mu \mathrm{m}$ cpx-reaction rim with the basanite host. Its interior shows equilibrated grain textures and, therefore, probably represent older dunitic cumulates from unrelated mafic magmas. Some low-Fo/high-NiO olivine compositions fall distinctly above the general $\mathrm{Fo}-\mathrm{Ni}$ trends (Figs. 5, 6) and their mantles show increasing Fo at constant Ni. Such olivine core compositions may be strongly affected by extended diffusion with a more evolved host magma, reflecting the faster $\mathrm{Mg}-\mathrm{Fe}$ interdiffusivity compared to Ni. These cores have later been overprinted by a second diffusive exchange with more mafic magma, thus creating the horizontal trend between core and mantles in Fo-NiO space (Fig. 5).

The xenolithic olivine of the sample DEU (14 analyses) from the West Eifel show exclusively the high-Fo/high-NiO composition $\left(\mathrm{Fo}_{88.7-89.1}, \mathrm{NiO}=0.3-0.4 \mathrm{wt} \%\right)$, but these compositions are still more evolved than some of the phenocrysts analyzed in West Eifel nephelinite.

\section{Temperature constraints for Laacher See hybrids}

Olivine-spinel pairs from Laacher See hybrids give 1047-1145 ${ }^{\circ} \mathrm{C}$ (average: $1106 \pm 43^{\circ} \mathrm{C}$ ) for $\mathrm{Fo}_{86-87}$ cores and $1162-1218{ }^{\circ} \mathrm{C}$ (average: $1172 \pm 32{ }^{\circ} \mathrm{C}$ ) for $\mathrm{Fo}_{89}$ mantles. These core temperatures for $\mathrm{Fo}_{86-87}$ olivine-spinel pairs are 
only slightly above the temperature of $1060{ }^{\circ} \mathrm{C}$ for hybrids estimated by Wörner and Wright (1984) for the equilibrium of olivine inclusions $\left(\mathrm{Fo}_{85}\right)$ in clinopyroxene in the same rock types from the same stratigraphic ULST section (their sample 1099-12). Olivine-spinel temperatures calculated here reflect crystallization temperatures at the time when the spinel was enclosed in the growing olivine crystals. The thermometer is not sensitive to re-equilibration during cooling of the lavas or after mixing with lower temperature phonolite due to the very slow diffusion of $\mathrm{Al}$ in olivine (Coogan et al. 2014). Therefore, average mantle-temperatures of around 1150 to $1170{ }^{\circ} \mathrm{C}$ likely represent the maximum temperatures during olivine crystallization and subsequent mixing between different basanite magmas during ascent and these temperatures should apply to the diffusive exchange between core and Fo-richer mantle. However, after hybridization with relatively "colder" mafic phonolite magma $\left(880{ }^{\circ} \mathrm{C}\right.$, Wörner and Schmincke 1984a, b; Berndt et al. 2001), the temperature range at which the olivine crystals started to equilibrate with the new equilibrium composition must have been significantly lower, within the range between 1170 and $880^{\circ} \mathrm{C}$. Since the hybrid samples show a large range of compositions along a mixing trend (Wörner and Wright 1984), the relative proportions of basanite to phonolite, and thus the temperatures after hybridization, were highly variable, which must be considered in the modeling of diffusion in the rims.

\section{Temperature constraints for mafic lavas erupted at the Rothenberg and Eppelsberg scoria cones}

Temperatures were constrained from spinel inclusions in olivine for the mafic samples from the Rothenberg and the Eppelsberg basanite. In the basanite samples, spinel inclusions with an adequate size for analysis and compositions within the calibration range of the thermometer are rare. Within the sample from Rothenberg, some of the inclusions were compositionally close to Ti-bearing magnetite and only crystallization temperatures for $\mathrm{Fo}_{84-86}$ could be constrained (1152-1170 ${ }^{\circ} \mathrm{C}$, average: $1159 \pm 23{ }^{\circ} \mathrm{C}$ ). For the sample from Eppelsberg basanite, crystallization temperatures of 1157-1202 ${ }^{\circ} \mathrm{C}$ (average: $1183 \pm 26^{\circ} \mathrm{C}$ ) are constrained only for less forsteritic olivine compositions $\left(\mathrm{Fo}_{83-84}\right)$.

\section{Pressure constraints}

For Laacher See hybrid clasts we took a minimum pressure of $2 \mathrm{kbar}$ for diffusion modeling based on the depth of the magma chamber constrained by previous workers (Wörner and Schmincke 1984a; Berndt et al. 2001; Harms et al. 2004). A similar pressure estimation is used for the Eppelsberg and Rothenberg basanites. The error caused by uncertain pressure values is negligible with respect to the uncertainty of temperatures.

\section{Our approach to diffusion modeling}

Olivine crystals from the final products of the Laacher See eruption are used here to constrain their growth history and residence times in the late-erupted mafic, hybrid host magma. As a complement, olivine from basanite lavas (bombs, lapilli and dikes) from several nearby (but significantly older) basanite scoria cones were also analyzed to constrain ascent times of mafic recharge magmas from mantle or lower crustal depths. Since for these samples we concentrate only on the outer diffusion boundaries between core and crystal rims, these diffusion times should represent the timespan between entrainment of olivine crystals into a new magma and their rapid cooling after eruption at the surface. We term this point of entrainment as reactivation time of older olivine crystals (Sundermeyer et al. 2020). Olivine crystals can be reactivated from prior storage in a crystal mush or cogenetic cumulates, or from a resident, more evolved magma by a newly ascending more mafic magma. On the other hand, olivine crystals may be carried up in mafic magmas from depth into shallower reservoirs where they mix with evolved, olivine-free magma. The compositional relations between olivine (Fo-content) and hybrid magmas (Mg\#) will depend on which of these processes was operating. In any case, the magma mixing event initiates diffusive re-equilibration of olivine cores to the new equilibrium composition of the new hybrid host magma. Given a sufficiently long time, which mostly depends on temperature and size of the crystals, the core may completely homogenize with the new surrounding magma. However, if this process remains incomplete (e.g. due to fast eruption or cooling during the eruption), the compositional gradient between mantle and core can be used to determine the timescales of equilibration and the original core compositions can constrain parent magma compositions. In our samples, the olivine crystals often show an additional very thin (few microns) zoned overgrowth at the outermost rim, which is the product of a late, short crystallization from the host matrix after mixing and/or diffusion event that reflects a final phase of ascent and cooling after eruption.

Zones of growth and diffusion, both forming compositional gradients, and growth during diffusion must be identified for diffusion modeling (Shea et al. 2015). Neglecting the effect of growth will result in an overestimation of the modeled timescales (Costa et al. 2008). However, there are several ways to distinguish diffusion from growth zoning. Compositional maps that focus on sharp crystal apexes show different zoning patterns for growth and diffusion: while growth zoning will produce compositional zones strictly parallel to the crystal faces, thus mimicking the crystal apexes, 
diffusion will produce smooth rounded zonation haloes across the apexes. Figure 3 shows an example of such diffusive smoothing around crystal apexes and thus suggests that zoning in these olivine crystals from Laacher See hybrids results from diffusion. The comparison of fast $(\mathrm{Mg}-\mathrm{Fe})$ and more slowly diffusing elements $(\mathrm{Ni}, \mathrm{Al}, \mathrm{P})$ is an additional tool to distinguish whether compositional gradients are induced by diffusion or growth. Line profiles for $\mathrm{Ni}$, $\mathrm{Al}$, and $\mathrm{P}$ show significantly steeper and narrower gradients compared to the Fo-content between both core/mantle and mantle/rim (Fig. 4). Therefore, this is solid evidence that the $\mathrm{Mg}-\mathrm{Fe}$ gradients are the result of a diffusion-dominated process. Further, the relationship between Fo-content and $\mathrm{NiO}$ also allows distinguishing growth from diffusion due to the different diffusion of $\mathrm{Mg}-\mathrm{Fe}$ and $\mathrm{Ni}$ (Gordeychik et al. 2018). For normally zoned olivine, growth results in a steep convex trend from core to mantle in a NiO-Fo diagram (Fig. 5). In contrast, it may be expected that diffusion is characterized by generally shallower trends (concave in normal zoned crystals and convex in reverse zoned crystals) if interdiffusion of $\mathrm{Mg}-\mathrm{Fe}$ is faster compared to the diffusion of Ni. The core-to-mantle gradients in olivine from East Eifel mafic lavas and Laacher See hybrids show a shallow trend from core to mantle and mantle to rim thus also suggest that these gradients are dominated by diffusion.

Diffusion profiles were modeled with both, a non-isothermal model that considers cooling of the melt during diffusion following the temperature constraints given above and an isothermal approach (DIPRA; Girona and Costa 2013). For both models, we assumed a step model for the compositional change between the core with an initial composition $\mathrm{C}_{1}$ and the high-Fo mantle with a composition $\mathrm{C}_{2}$. It is unconstrained whether the outermost rim already existed during diffusive exchange between core and mantle. Therefore, either, this mantle evolved in a second stage of diffusion to the low-Fo composition $\mathrm{C}_{3}$ of the rim or the rim formed later and was then modified by diffusion. If a wider rim already existed during core-mantle diffusion, then a s-shaped diffusion profile may have existed that was later (partly) removed by dissolution and/or modified by rim diffusion. However, a significant resorption event between mantle and rim is not indicated by the lack of distinct resorption interfaces that otherwise would be documented by slowly diffusing elements (e.g. Al, P). We tested both scenarios in our model, one based on diffusion between core-mantle-rimmelt and one for diffusion between core-mantle-melt. We found that due to the narrow gradients $(<15 \mu \mathrm{m})$, the differences in calculated timescales are negligible and within the overall uncertainties of the model (see discussion below).

The diffusion models calculated below then provide two timescales for the Laacher See hybrid samples, which represent (1) the time between entrainment of olivine that is relatively low in Fo by a more mafic basanite and its intrusion into the phonolite magma chamber, and (2) the time between subsequent basanite/phonolite mixing, and eruption. For the Laacher See hybrids, we will first test an isothermal diffusion model based on the DIPRA algorithm (Girona and Costa 2013) and then a non-isothermal model (Petrone et al. 2016; Rout et al. 2020), and compare and evaluate the results. For the basanitic olivine we only model the inner diffusive boundaries. The gradients between the narrow mantle and the rim was not modeled at all for olivine from Eppelsberg and Rothenberg basanite, because the parallel gradients of Fo and slowly diffusing trace elements are similar and thus indicate a growth-dominated zonation (Fig. 4). Note, however, that all our models only return maximum timescales because (1) the Laacher See eruption lasted several days with the hybrid magmas being erupted towards the very end and the duration of the ongoing eruption would be part of the calculated diffusion times; and (2) for basanite lava and dike samples from scoria cones it cannot be excluded that diffusion continued after the eruption due to non-instantaneous cooling.

\section{Diffusion modeling using DIPRA}

The software DIPRA calculates timescales using a finite 1-dimensional, numerical modeling approach and the diffusion coefficients, that were experimentally determined by Petry et al. (2004), Coogan et al. (2005), Dohmen and Chakraborty (2007) and Dohmen et al. (2007). The model considers the change of Fo content in the olivine with time due to diffusion and thus the compositional dependence of changing diffusion coefficients (Girona and Costa 2013). In all analyzed olivine crystals, the diffusion of $\mathrm{Mg}-\mathrm{Fe}, \mathrm{Mn}$, $\mathrm{Ca}$, and $\mathrm{Ni}$ was modeled separately. A detailed overview of all modeling parameters is given in Online Resource 4 (Fig. 9).

The software uses the root-mean-square-method (rms) to find the best-fit model curve (Girona and Costa 2013). For this, the initial concentrations $C_{1}, C_{2}$, and $C_{3}$ must be defined. Within a number of steps $\mathrm{d} t$ and $\mathrm{d} x$ in time and space, which must be provided, DIPRA searches the best-fit between the measured profile and the model curves for every time and space step:

$\mathrm{rms}=\sqrt{\frac{1}{N} \sum N\left(C_{i}^{x_{j} j}-C_{i}^{x}\right)^{2}}$,

with $N$ as the number of data points, $C_{j}^{x}$ being the measured concentration $C$ of an element $i$ at a distance $x$, and $C_{i}^{x, j}$ being the modeled concentration $C$ of an element $i$ at a distance $\times$ after $\mathrm{j}$ time steps (Girona and Costa 2013).

Since the cooling rate and temperature distribution is unknown, diffusion times were calculated (1) at an intermediate temperature implying only minor cooling and (2) 

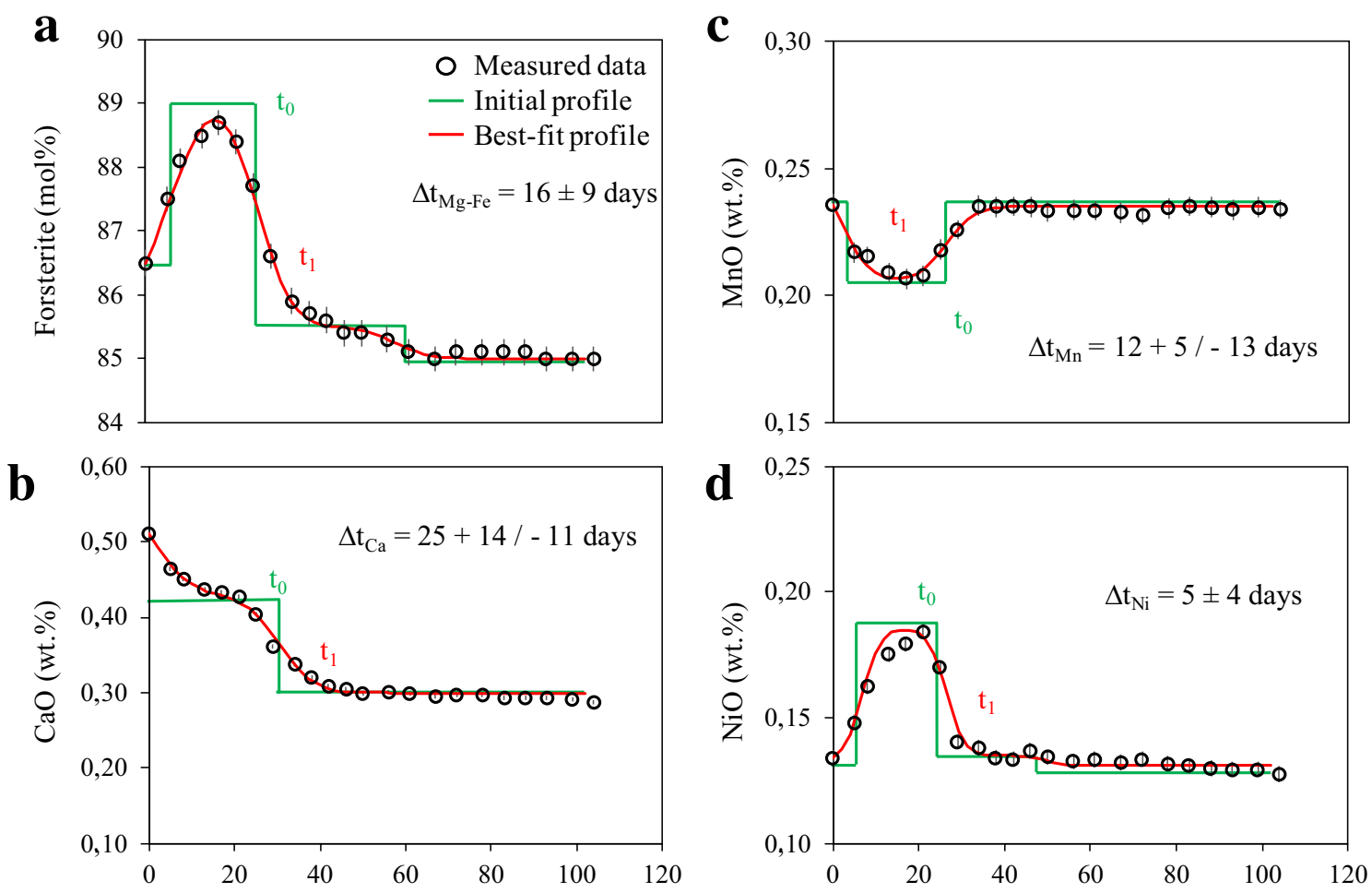

Fig. 9 Isothermal diffusion modeling of $\mathbf{a ~} \mathrm{Mg}-\mathrm{Fe}, \mathbf{b} \mathrm{Ca}$, $\mathbf{c ~ M n}$, and $\mathbf{d}$ $\mathrm{Ni}$ in a representative olivine crystal from the Laacher See (LSH-1-1) using DIPRA (see text for discussion and explanations). Green lines show the estimated initial zoning at the time $t_{0}$, when the olivine is reactivated and starts diffusive equilibration for a timespan $\Delta t$ until

a minimum temperature assuming that the main part of the diffusion took place in the colder hybrid melt. The intermediate temperature is defined as $T_{\text {effective }}=0.95 * T_{\text {calculated }}$ (Chakraborty and Ganguly 1991; Costa et al. 2008). This relationship is defined for element diffusion with activation energies $E_{a}=200 \mathrm{~kJ} \mathrm{~mol}^{-1}$ (Chakraborty and Ganguly 1991; Costa et al. 2008). This is in the range of the activation energies for diffusion in olivine used in the software DIPRA (Diffusion Process Analysis) by Girona and Costa (2013): $E_{\mathrm{Fo}}=201 \mathrm{~kJ} \mathrm{~mol}^{-1}, E_{\mathrm{Mn}}=201 \mathrm{~kJ} \mathrm{~mol}^{-1}, E_{\mathrm{Ni}}=220 \mathrm{~kJ} \mathrm{~mol}^{-1}$, and $E_{\mathrm{Ca}}=193-207 \mathrm{~kJ} \mathrm{~mol}^{-1}$ depending on the crystallographic orientation. The estimation of an effective temperature close to the maximum temperature is based on the exponential dependency of the diffusion coefficient on $\mathrm{T}$. Therefore, the major part of diffusion occurred at the beginning of the diffusion process, when temperatures are still high (Costa et al. 2008). This estimation results in effective temperatures $T_{\text {effective }} \sim 1114{ }^{\circ} \mathrm{C}$ for Laacher See, $1101{ }^{\circ} \mathrm{C}$ for Rothenberg, and $1123{ }^{\circ} \mathrm{C}$ for Eppelsberg samples.

The minimum temperatures for the hybrid can be estimated taking the calculated temperatures for the olivine mantles $\left(1172{ }^{\circ} \mathrm{C}\right)$, the temperature of $\sim 880^{\circ} \mathrm{C}$ for the mafic phonolite (Berndt et al. 2001), and the average $40 / 60 \%$ ratio diffusion is interrupted at the time $t_{1}$ (red line) by cooling (e.g. eruption). The time obtained by modeling a curve best-fitting the measured profile represents the timescales between entrainment by the basanite and eruption

of phonolite/basanite mixing proportions by Wörner and Wright (1984) as $\sim 1055{ }^{\circ} \mathrm{C}$. However, the proportions of basanite/phonolite cannot be assumed to be the same for all hybrid samples. Considering the uncertainty of the Coogan et al. (2014) thermometer and the $30 \%$ basanite component being a minimum value, we estimate a minimum temperature of $T=1000^{\circ} \mathrm{C}$ for the temperature of the hybrid hosts.

For error calculation we used the $2 \sigma$-uncertainties obtained from the analytical measurements ( $\mathrm{Fo}=0.2 \mathrm{~mol} \%$, $\mathrm{Mn}=0.004 \mathrm{wt} \%, \mathrm{Ca}=0.003 \mathrm{wt} \%$, and $\mathrm{Ni}=0.003 \mathrm{wt} \%$ ), and the standard deviations from the calculation of $T_{\text {effective }}$ that include the uncertainty given for the thermometer $\left( \pm 20^{\circ} \mathrm{C}\right.$, Coogan et al. 2014). The uncertainties for $T$ are $\pm 32{ }^{\circ} \mathrm{C}$ for Laacher See hybrid samples, $\pm 23^{\circ} \mathrm{C}$ for Rothenberg, and $\pm 26^{\circ} \mathrm{C}$ for Eppelsberg. Temperature is the dominant parameter controlling diffusion and, therefore, uncertainties in calculated diffusion times. The uncertainties for $T$ used here result in time uncertainties that are mostly in the range of $26-78 \%$ for diffusion modeling of $\mathrm{Mg}-\mathrm{Fe}, 32-119 \%$ for $\mathrm{Mn}, 29-104 \%$ for $\mathrm{Ca}$, and $30-130 \%$ for $\mathrm{Ni}$, but can reach up to $300 \%$ for crystals with very short diffusion times (days) and a low compositional contrast between core, mantle, and rim. 


\section{Non-isothermal modeling}

The distinct compositional zones observed in olivine crystals may have formed at different times and temperatures. These processes can be modeled using a non-isothermal diffusion model e.g. NIDIS (Non-Isothermal Diffusion Incremental Step model) from Petrone et al. (2016), which was recently modified by Rout et al. (2020). This model allows the stepwise modeling of diffusion in complex zoned crystals at different temperatures. The core started diffusive equilibration with the mantle composition at a time $t_{1}$ and a temperature $T_{1}$, and equilibrated for a timespan $\Delta t_{1}$. After that time, the rim is formed and the mantle started equilibration with the rim composition (at a time $t_{2}$ and a temperature $T_{2}$ ). During the time span $\Delta t_{2}$ the rim equilibrates, but simultaneously the core equilibration continues its diffusive exchange at the different temperature $T_{2}$. The sum of the times $\Delta t_{1}$ and $\Delta t_{2}$ represents the total time of diffusion (Petrone et al. 2016).

The non-isothermal model used in this study is based on a 1-dimensional, numerical approach as described by Costa et al. (2008). The diffusion times were calculated using initial compositions, pressure and min./max. temperature values identical to the isothermal model. Since the cooling rates are unknown, we decided to model diffusion in olivine from the Laacher See hybrids with a stepwise cooling, assuming a rapid temperature decrease when the basanite entered the Laacher See magma chamber and mixed with the colder phonolite.

The non-isothermal modeling shows that the time $\Delta t_{1}$ of core-mantle diffusion high temperatures of $1114{ }^{\circ} \mathrm{C}$ to $1172{ }^{\circ} \mathrm{C}$ must have been very short (from hours to $<15$ days, see results below). This short time scale refers to the earlier basanite-basanite mixing event. The second stage of diffusion that affected the rims took part at low temperatures $\left(1000^{\circ} \mathrm{C}\right)$ then represents the major part of the entire diffusive history. The short timescales and the high temperature uncertainties result in relative time uncertainties of 80 to $>100 \%$. The timescales are consistent to those obtained from the isothermal modeling at $1000{ }^{\circ} \mathrm{C}$ in DIPRA due to the short diffusion period at high temperatures but yield higher relative errors.

\section{Results: calculated diffusion times}

Results of model calculations are summarized in Fig. 10 and Table 1. For olivine from the Laacher See hybrids, the timescales obtained from olivine core-mantle-rim zoning range from $1 \pm 1$ to $49+35 /-20$ days based on $\mathrm{Mg}-\mathrm{Fe}$ diffusion at $T_{\text {effective }}=1114{ }^{\circ} \mathrm{C}$. Maximum timescales at $1000{ }^{\circ} \mathrm{C}$ are up to 410 days. Diffusion times for trace elements are in good agreement and vary between $1-34(+25 /-12), 1-30$ $(+18 /-13)$, and 1-36 (+41/-28) days for $\mathrm{Mn}, \mathrm{Ca}$, and $\mathrm{Ni}$, respectively. The non-isothermal model yields very similar

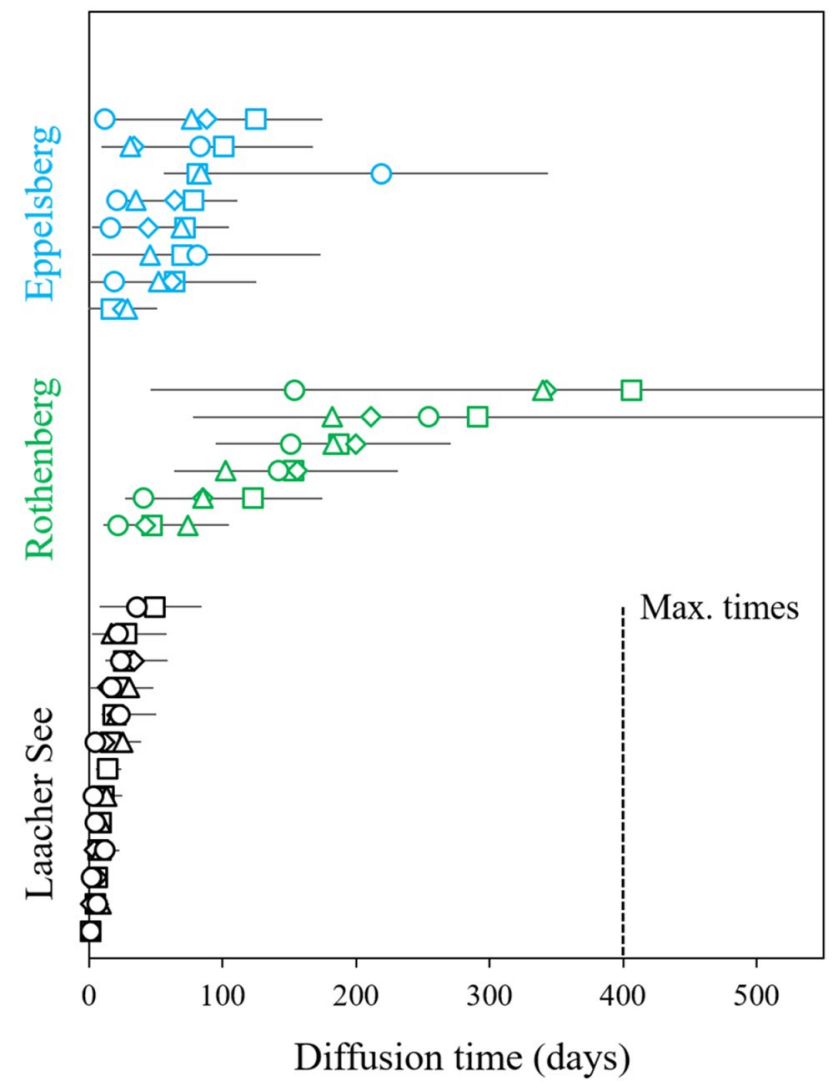

Fig. 10 Diffusion times of $\mathrm{Mg}-\mathrm{Fe}, \mathrm{Mn}, \mathrm{Ca}$, and $\mathrm{Ni}$ in olivine from Laacher See, Rothenberg, and Eppelsberg. Diffusion times of analyzed olivine crystals from Laacher See are exceedingly short ( $<50$ days) up to 415 days depending on the chosen model and temperature path. However, the timescales indicate that the phonolitic magma chamber was reactivated only within 2 to 14 months prior to eruption (maximum estimates). Olivine from the basanitic samples show maximum diffusion times, which vary from tens of days up to 400 days. Large uncertainties are mainly caused by temperature uncertainties

timescales of $<15$ days for core diffusion at $1114^{\circ} \mathrm{C}$ and up to 400 days for core and rim diffusion at $1000{ }^{\circ} \mathrm{C}$.

Diffusion times calculated for olivine from the basanite sample E41 at intermediate temperatures are generally longer (up to 406 days). Olivine from E41 gave a range of timescales between $47(+18 /-14)$ and $406(+238 /-126)$ days for $\mathrm{Mg}-\mathrm{Fe}$ diffusion. $\mathrm{Mn}, \mathrm{Ca}$, and $\mathrm{Ni}$ gave comparable results, except for one crystal E41-4-3, with $t_{\mathrm{Fo}}=406$ days and $t_{\mathrm{Ni}}=154(+64 /-82)$ days. However, given the uncertainties these diffusion times still overlap. Olivine from EPB gave shorter diffusion times of $17(+8 /-7)$ to 125 $(+52 /-50)$ days (maximum times along a-axis), which again correlate well with trace element diffusion times (12 $+12 /-8$ to $88+40 /-67$ days). 
Table 1 Diffusion times of olivine crystals from Laacher See mafic phonolite-basanite hybrid clasts (LS-samples) and Rothenberg (E41) and Eppelsberg (EPB) basanite

\begin{tabular}{|c|c|c|c|c|c|c|c|c|c|c|c|c|}
\hline \multirow[t]{2}{*}{ Crystal No. } & \multicolumn{3}{|c|}{$\mathrm{Mg}-\mathrm{Fe}$} & \multicolumn{3}{|l|}{$\mathrm{Mn}$} & \multicolumn{3}{|l|}{$\mathrm{Ca}$} & \multicolumn{3}{|l|}{$\mathrm{Ni}$} \\
\hline & Time & - & + & Time & - & + & Time & - & + & Time & - & + \\
\hline LS-A-2 & 7 & 4 & 4 & 4 & 3 & 4 & 9 & 4 & 5 & 12 & 6 & 11 \\
\hline LS-A-7 & 22 & 8 & 14 & 14 & 14 & 22 & 30 & 13 & 18 & 17 & 9 & 10 \\
\hline LS-B-1 & 1 & 1 & 1 & 1 & 1 & 3 & 1 & 1 & 1 & 1 & 1 & 1 \\
\hline LS-B-2 & 28 & 13 & 23 & 22 & 20 & 36 & 17 & 7 & 10 & 22 & 11 & 18 \\
\hline LSH-1-1 & 16 & 9 & 9 & 12 & 5 & 13 & 25 & 11 & 14 & 5 & 4 & 4 \\
\hline LSH-1-5 & 6 & 4 & 5 & 6 & 4 & 6 & - & - & - & 2 & 2 & 4 \\
\hline LSH-2-3 & 5 & 3 & 4 & 1 & 1 & 3 & 9 & 8 & 6 & 6 & 3 & 4 \\
\hline LSH-2-9 & 11 & 6 & 7 & 10 & 5 & 8 & 13 & 6 & 12 & 3 & 2 & 3 \\
\hline LSH-3-2 & 18 & 6 & 10 & 21 & 10 & 25 & 20 & 8 & 16 & 23 & 14 & 27 \\
\hline LSH-3b-2 & 14 & 9 & 10 & - & - & - & - & - & - & - & - & - \\
\hline $1101-3-3$ & 9 & 3 & 6 & 5 & 2 & 4 & 9 & 3 & 7 & 5 & 3 & 3 \\
\hline $1101-3-5$ & 49 & 20 & 35 & - & - & - & - & - & - & 36 & 28 & 41 \\
\hline $1101-3-6$ & 26 & 14 & 16 & 34 & 12 & 25 & - & - & - & 24 & 10 & 14 \\
\hline E41-4-1 & 291 & 213 & 103 & 211 & 61 & 159 & 182 & 80 & 77 & 254 & 167 & 346 \\
\hline E41-4-3 & 406 & 126 & 238 & 343 & 297 & 252 & 340 & 97 & 151 & 154 & 82 & 64 \\
\hline E41-4P-1 & 153 & 66 & 78 & 156 & 61 & 63 & 102 & 38 & 59 & 142 & 43 & 84 \\
\hline E41-4P-2 & 47 & 14 & 18 & 42 & 14 & 15 & 74 & 32 & 31 & 22 & 11 & 10 \\
\hline E41-4P-4 & 123 & 55 & 52 & 85 & 55 & 65 & 85 & 48 & 34 & 41 & 14 & 23 \\
\hline E41-4P-6 & 187 & 57 & 67 & 200 & 54 & 71 & 183 & 59 & 67 & 151 & 56 & 116 \\
\hline ЕРВ19-1-2xс2 & 78 & 33 & 33 & 64 & 27 & 30 & 35 & 18 & 16 & 21 & 8 & 10 \\
\hline EPB19-1-3id1 & 17 & 8 & 7 & 25 & 9 & 23 & 29 & 30 & 22 & - & - & - \\
\hline EPB19-1-3id2 & 64 & 42 & 42 & 62 & 38 & 63 & 52 & 16 & 37 & 19 & 19 & 37 \\
\hline EPB19-1-3id4 & 81 & 25 & 50 & - & - & - & 84 & 28 & 77 & 219 & 100 & 125 \\
\hline EPB19-1-3id5 & 101 & 53 & 67 & 34 & 25 & 24 & 31 & 13 & 23 & 83 & 40 & 40 \\
\hline EPB19-1-3id8 & 72 & 26 & 33 & 44 & 26 & 26 & 69 & 37 & 28 & 16 & 14 & 12 \\
\hline EPB19-2-2id3 & 125 & 52 & 50 & 88 & 67 & 40 & 77 & 24 & 42 & 12 & 8 & 12 \\
\hline EPB19-2-2id4 & 70 & 28 & 39 & - & - & - & 46 & 26 & 26 & 81 & 79 & 92 \\
\hline
\end{tabular}

Diffusion times from EPB are maximum times calculated for diffusion along the a axis

\section{Discussion: implications for magmatic evolution and eruption}

Olivine compositions and zoning patterns show that basanite from the East and nephelinite magmas from the West Eifel volcanic field are distinct in their composition, origin, and histories. Both are again different from olivine contained in the basanite magma that intruded into the Laacher See magma system within weeks to months before its eruption $13 \mathrm{kyr}$ ago. The observation that olivine from the East Eifel basanite samples are less forsteritic (corresponding to more evolved magmas) than those from the West Eifel, correlates with the generally more evolved volcanic products in the East Eifel compared to the more primitive composition of magmas in the West Eifel (Schmincke 2007). Our analyses of olivine crystals reveal two distinct trends for East and West Eifel volcanic products with respect to their Fo- and NiOrelationship (Fig. 6a). Olivine core compositions from the West Eifel nephelinite samples fall on a steep crystallization trend of mantle-derived melts starting from an equilibrium composition with $>\mathrm{Fo}_{90}$ and high $\mathrm{NiO}(>0.3 \mathrm{wt} \%)$. The near primary nature of these West Eifel nephelinite magmas is also indicated by the abundance of mantle-derived peridotite xenoliths (e.g. sample DEU from the Meerfelder Maar; WittEickschen et al. 2003) and high-pressure cumulates from the base of the crust (PUL: Pulvermaar; Lloyd 1987; Duda and Schmincke 1985).

The reverse zoning pattern commonly found in olivine from East Eifel basanite samples indicate a common history for most basanite-derived olivine crystals and their host magmas, which is different from that of the nephelinites. The compositional range of their cores results from mixing of variably evolved basanitic melts with equilibrium olivine of $<\mathrm{Fo}_{88}$ and low $\mathrm{NiO}(<0.2 \mathrm{wt} \%)$. The typical reverseloop zonation starting from these cores towards a relatively uniform, more forsteritic mantle $\left(\mathrm{Fo}_{86.5-87.5}\right)$ indicate that these magmas and their olivine crystals mixed after previous storage with new ascending, more mafic basanite magmas.

The uniform composition of olivine mantles $\left(\sim \mathrm{Fo}_{86.5-87.5}\right.$, $\mathrm{NiO}=0.1-0.2 \mathrm{wt} \%)$ marks 
(1) the maximum Fo-content found in olivine cores from East Eifel basanite

(2) the common mantle composition, to which all cores equilibrated.

(3) to the common composition of olivine rims from Laacher See hybrids.

(4) the minimum Fo- and NiO-content found in olivine mantles/rims in West Eifel nephelinite samples, whose magnesian cores represent primary magma compositions (Fig. 6a-c, 8). Thus, this composition is common to all samples that we studied and is intermediate between more evolved basanite and primary mantlederived melts.

\section{History and composition of the Laacher See recharge magma}

It was previously assumed that the basanite recharging into the Laacher See magma chamber is equivalent to magmas previously erupted in older basanitic scoria cones surrounding the Laacher See volcano (Wörner and Wright 1984). However, the cores of olivine crystals in Laacher See hybrids show a large compositional range that extends from $\mathrm{Fo}_{83}$ to $>\mathrm{Fo}_{88}$ (Fig. 6a) and their mantle compositions even reach up to $\mathrm{Fo}_{89.1}$ and $\mathrm{NiO}=0.24 \mathrm{wt} \%$. Such high-Fo and intermediate $\mathrm{NiO}$ composition is neither observed in East Eifel basanite nor West Eifel nephelinite and extends the trend of olivine cores from basanites towards a more magnesian composition (Fig. 6a). The less forsteritic compositions within this large range in olivine core compositions overlap with those of olivine erupted in basanite magmas
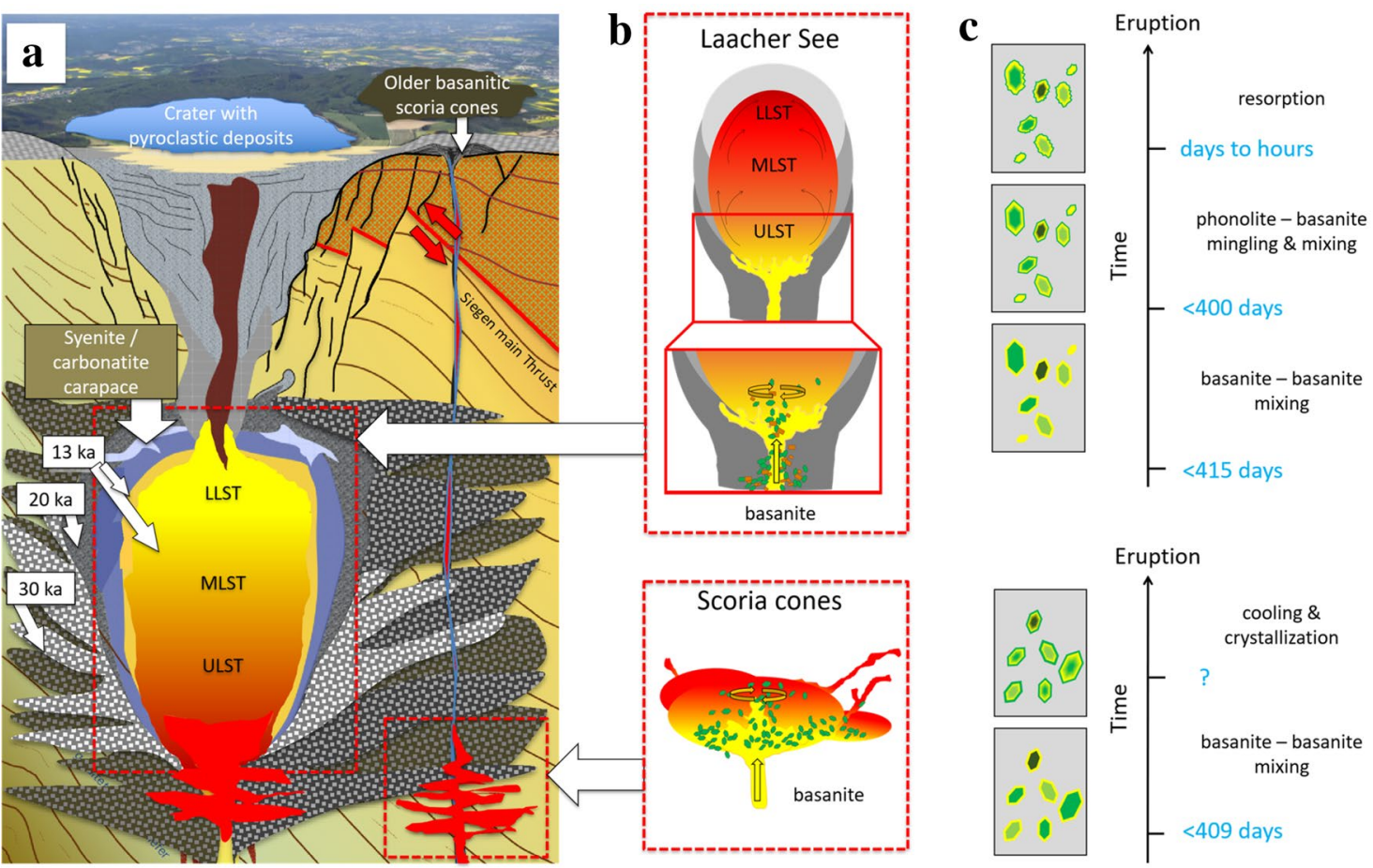

Fig. 11 a Schematic model of the magmatic systems beneath the basanitic scoria cones and the Laacher See volcano [after earlier concepts developed in (Wörner and Schmincke 1984b; Tait et al. 1989; Ginibre et al. 2004; Schmitt et al. 2010)] with depth constraints from xenolith evidence and experimental petrology (Wörner et al. 1982; van den Bogaard and Schmincke 1984; Wörner and Schmincke 1984b; Berndt et al. 2001; Harms et al. 2004). The model shows (in an inverted sense) the compositional zonation from ULST to MLST and LLST phonolite magma as a molten core from which the eruption occurred $13 \mathrm{kyr}$ ago. This core is embedded in an intrusive carapace of older and colder syenite-carbonatite and cumulate rocks that are found as abundant cogenetic lithics in the tephra deposit (Tait et al. 1989; Rout and Wörner 2018). These syenites and cumulates have been dated (Bourdon et al. 1994; Schmitt et al. 2010) to range in

age from 13 to $30 \mathrm{ka}$, they also have quenched interstitial phonolitic glass and thus represent the extended residence time of the active phonolitic magma system in the shallow crust. b Shows zooms of the magma reservoirs at the base of the phonolitic Laacher See volcano and the nearby basanitic scoria cones. The processes of recharge, crystal reactivation, mixing and their timing are in detail shown in c. Mafic recharges connected to basanite-basanite mixing and olivine reactivation occurred both, at the Laacher See volcano and the scoria cones at Eppelsberg and Rothenberg $~ 410$ days prior to the eruption. At Laacher See volcano, the basanite subsequently entered the phonolitic magma reservoir and mixed/mingled with the mafic phonolite in the lower part of the chamber $<400$ days prior to the eruption. Aerial photo of the Laacher See crater (inset) provided by Walter Müller 
at the scoria cones. This indicates that some of the olivine crystals in the recharging basanite initially had similar histories compared to those erupted at the scoria cones. However, the additional presence of more magnesian olivine crystal cores and also distinctly more magnesian overgrowths on all olivine crystals in the Laacher See hybrids then indicate that the recharging basanite must have had a different history and composition compared to the basanites that erupted in nearby scoria cones (Figs. 5, 6b, 11).

There are two important conclusions from this observation:

(1) before entering the Laacher See magma chamber, the recharging basanite entrained olivine crystals with a range of compositions that were stored either in a crystal mush or contained in basanite magma in the crust at the time when the Laacher See volcano erupted. Most of these crystals are similar to those known from erupted basanites in the East Eifel. However,

(2) the new basanite magma was significantly more mafic than any of the basanites erupted from the nearby scoria cones. Only the outer rims of olivine crystals from the hybrids are uniform and again less magnesian in composition $\left(\mathrm{Fo}_{86.5-87.5}\right.$, Fig. $\left.6 \mathrm{c}\right)$ and thus reflect the composition in equilibrium with the hybrid matrix that formed after basanite-phonolite mixing.

\section{Origin and mixing history of basanite magmas in the East Eifel}

Distinct growth zones in olivine crystals from the basanite samples shown by $\mathrm{P}$ - and $\mathrm{Al}$-content are evidence for several heating events (Milman-Barris et al. 2008) that may reflect frequent basanite-basanite mixing events as documented also from eruptive products of the WEVF (Shaw and Klügel 2002; Shaw 2004). The basanite magmas from the scoria cones are either products of mixing between mafic magmas with variable, slightly more evolved magmas or they entrained cumulate crystals of variable composition from an older residual crystal mush. The observed compositional range of low-Fo olivine cores is consistent with both interpretations. Since no magnesian olivine cores $>\mathrm{Fo}_{88}$ are found in basanite lavas, the mafic endmember of mixing cannot have been a primary magma which would be expected to carry olivine $>\mathrm{Fo}_{90}$ as is recorded in West Eifel nephelinites. Except for the recharge magma that formed the Laacher See hybrids, there is no evidence for primary basanite magmas in our samples from the East Eifel. However, both the erupted basanites and the basanite endmember of the Laacher See hybrids share the "common" composition at $\mathrm{Fo}_{86.5-87.5}$ (yellow field in Figs. 5,7). Such a composition could in principle be produced by mixing of variably evolved basanite magma as represented by the range in olivine core compositions
$\left(\mathrm{Fo}_{80}\right.$ to $\mathrm{Fo}_{86}$; Fig. 6) and a recharge magma that is in equilibrium with $\mathrm{Fo}_{89}$, i.e. the most mafic mantle composition observed in olivine crystals contained in the hybrids (circled "basanite" field in Fig. 5).

However, this brings up the question why this $\mathrm{Fo}_{89} \mathrm{com}$ position itself is completely absent in olivine crystals from the basanite samples from scoria cones but so prominent in all crystals from the basanite-phonolite hybrids. Whatever the reason is for this difference, this observation must indicate the distinct character of the particular basanite magma that mixed with, and possibly triggered the eruption of the Laacher See phonolite.

One possible explanation for the absence of mantles with $\mathrm{Fo}_{89}$ in olivine crystals from the basanite samples may be due to their advanced equilibration by diffusion at high temperatures $\left(\sim 1100{ }^{\circ} \mathrm{C}\right)$, during which initially Fo-rich compositions must all have re-equilibrated towards the common, less forsteritic composition found in the basanites. Diffusion modeling shows that a narrow mantle with $\mathrm{Fo}_{89}$ can equilibrate to $\mathrm{Fo}_{86}$ within tens up to few hundred of days, which is in the range of diffusion times calculated in this study.

This scenario implies that:

(1) scoria cones are fed from basanite magmas with an extended history (up to $>1$ year) of crustal transfer, residence, and basanite-basanite mixing connected to olivine reactivation from crystal mushes/cumulates, and

(2) the recharging basanite the Laacher See magma reservoir had a distinct history: it must have risen directly from mantle magma reservoirs in shorter time (possibly $<15$ days as evidenced from olivine core diffusion times) and mixed with the phonolite less than 400 days prior to eruption. This interpretation has profound implications for assessing precursor activity of potential future eruptions in the region.

\section{What happened prior to the eruption of the Laacher See volcano?}

The pre-eruptive processes, eruption triggering events and the timescales of reactivation of the Laacher See magmatic system have long been subject to study, but details remain unclear. U-Th isotope dating of minerals that crystallized from the Laacher See phonolite magma has clearly shown that evolved phonolitic magmas resided for more than 20,000 years below the Laacher See volcano before it eventually erupted (Bourdon et al. 1994; Schmitt 2006; Schmitt et al. 2010). This naturally begs the question why phonolite magmas did not erupt earlier and what was the final triggering event. It is known from other volcanic settings that mafic recharge events and subsequent magma mixing may 
cause precursor geophysical activity (e.g. Kahl et al. 2011, 2013; Sundermeyer et al. 2020) and eventually trigger eruptions (Sparks et al. 1977; Murphy et al. 2000; Eichelberger et al. 2006; Wright et al. 2011; Ruprecht and Plank 2013; Cashman and Giordano 2014; Wolff et al. 2015; Wiebe 2016). Therefore, with respect to the Eifel Volcanic fields, it is important to understand ascent and mixing time scales for mafic magmas. To this end, diffusion times of olivine were already calculated for several primitive eruptive centers in the West Eifel such as Baarley, Gemündener Maar, and Meerfelder Maar (Shaw and Klügel 2002; Shaw 2004). Zoned olivine in xenoliths document fast ascent times from the mantle and probably several recharge events years prior to the eruption (Shaw 2004) with only months to hours between the last mixing, degassing, and eruption (Shaw and Klügel 2002; Denis et al. 2013; Shaw et al. 2018).

Diffusion times of olivine crystals analyzed in this study indicate similar timescales for the ascent of the basanite ( $<15$ days) that intruded into the Laacher See phonolite magma system less than 400 days before the cataclysmic eruption $13 \mathrm{kyr}$ ago. Several earlier recharge events were suggested by Rout and Wörner (2020) to have occurred during the 20,000 years history of phonolite magma residence but these apparently did not result in eruptions.

Using diffusion modeling of zoned sanidine phenocrysts from carbonatitic syenites representing the top and margins of the magma chamber (Fig. 11a), Rout and Wörner (2018) proposed a final heating and destabilization event within years prior to the eruption. This event is not preserved in the olivine crystals likely due to re-equilibration. However, Rout and Wörner (2018) also modeled diffusive re-equilibration of exsolution lamellae in sanidines, that formed during a period of relatively cold storage in the syenitic, crystal-rich carapace surrounding the magma reservoir. These indicate heating above the solvus of $725^{\circ} \mathrm{C}$ within 15-50 days prior to the eruption. Such timescales are consistent with short olivine diffusion times calculated in this study at $T=1114^{\circ} \mathrm{C}$. The temperatures estimated for the syenites surrounding the phonolite are $\sim 325-400{ }^{\circ} \mathrm{C}$ lower than those calculated here for from olivine-spinel pairs from the basanite intruding into the base of the magma system. A strong temperature gradient must have existed between the LLST syenites, the evolved phonolite at the top to the mafic phonolite, phonolitic crystal mush, and the intruding basanite at the bottom. Such a temperature gradient was already estimated by Wörner and Wright (1984) between the LLST to ULST phonolite $\left(800-860{ }^{\circ} \mathrm{C}\right)$ and the mafic hybrids $\left(1060{ }^{\circ} \mathrm{C}\right)$. This also supports the hypothesis that magma mixing/heating was restricted to the bottom of the reservoir as also indicated by the occurrence of hybrid components only in the uppermost ULST (i.e. the lowermost part of the magma chamber; Wörner and Wright 1984; Tait et al. 1989; Berndt et al. 2001; Ginibre et al. 2004).
As outlined above, the olivine crystals in the hybrid magmas had a history distinct from those found in basanitic scoria cones and were entrained into the basanite magma only shortly before mixing and eruption (Fig. 11c). However, it is unconstrained whether these olivine crystals were stored before entrainment in a crystal mush at the bottom of the Laacher See magma chamber, i.e. resulted from the previous intrusions of basanite documented by Rout and Wörner (2020) or whether these olivine crystals were derived from a deeper reservoir below (and not directly connected to) the Laacher See magma reservoir. We can, however, speculate that previous basanite intrusions were not able to enter the Laacher See magma chamber directly due to the nearly-rigid crystal mush functioning as a temporary barrier (Pallister et al. 1992) until a particularly strong recharge event brought new, near-primary magma from deep (mantle) levels.

The narrow range of timescales indicates that the final and critical recharge was a single event rather than an extended phase of continuous intrusions. Previous studies (Folch and Martí 1998; Snyder 2000; Wark et al. 2007) showed that mafic recharge events can trigger silicic eruptions within months even without wholesale magma mixing, simply due to over-pressurization caused by volatile exsolution from the cooling and crystallizing recharge magma. A similar scenario is assumed to have triggered the 1991 Pinatubo eruption (Pallister et al. 1992; Kress 1997; Folch and Martí 1998) and may be also reasonable for Laacher See.

Our results show that the phonolitic magma chamber can be activated and brought to eruption within maximum 400 days after an extended storage time of tens of thousands of years by a single critical recharge event. Given the uncertainties in such diffusion modeling, this timescale is consistent with estimates by Rout and Wörner (2020) based on diffusion modeling of $\mathrm{Ba}$ in sanidines from the same rocks that gave maximum diffusion times of 1.5-3 years after phonolite-basanite mixing. Whether or not an additional trigger was related to $\mathrm{CO}_{2}$-degassing from the recharge basanite and the effect of $\mathrm{CO}_{2}$-flushing on the phonolite magma (Caricchi et al. 2018) remains to be investigated.

\section{Conclusions}

Magmatic processes prior to the phonolitic Laacher See eruption (13 kyr) have been reconstructed with respect to their timescales and the composition of involved magmas using compositions and diffusion modeling in olivine crystals from the hybrid phonolite-basanite tephra clasts that were produced at the very end of the eruptive sequence. These hybrids were interpreted to have formed after intrusion of basanite magma into the lowermost part of a chemically zoned phonolite magma chamber. 
The composition and zonation of olivine crystals constrain the pre-eruptive history of the evolved Laacher See magma reservoir after $20 \mathrm{kyr}$ of storage:

1 Laacher See hybrids that formed from basanite-phonolite mixing and mingling contain olivine crystals that show complex reverse zonation with variable cores $\left(\mathrm{Fo}_{83-89}\right)$ and more magnesian mantles with $\mathrm{Fo}_{87.8-89}$.

2 Compositional mapping and measured profiles show that the smooth compositional gradients between core and mantles formed by diffusion and partial equilibration after entrainment by a more mafic basanite magma.

3 The basanite that intruded into the resident Laacher See phonolite reservoir was distinctly more mafic than basanites erupted in nearby scoria cones. This recharging basanite contained olivine crystals that were entrained from older intrusions during ascent $<15$ days before entering the Laacher See magma system.

4 Mixing of mafic basanite and the crystal-rich phonolite magma at the base of the Laacher See magma chamber resulted in hybrids that are in equilibrium with $\mathrm{Fo}_{86.5-87.5}$ as shown by the outermost olivine rim compositions.

5 Basanite lavas erupted from the older scoria cones surrounding Laacher See volcano represent more evolved compositions as represented by their less forsteritic olivine cores $\left(\mathrm{Fo}_{80-88}\right)$ compared to the basanite recharging the Laacher See reservoir $\left(\mathrm{Fo}_{89}\right)$. These cores equilibrated after mixing with intermediate hybrid magmas (in equilibrium with $\mathrm{Fo}_{86.5-87.5}$ ).

6 We document short diffusion times for the compositional zonation in olivine crystals from the Laacher See hybrids. The olivine crystals started diffusive equilibration with the mafic basanite $\left(\mathrm{Fo}_{89}\right)$ less than 15 days before entering the Laacher See magma chamber. Subsequently the crystals further exchanged by diffusion to the new hybrid host $\left(\mathrm{Fo}_{86.5-87.5}\right)$ after phonolite-basanite mixing for maximum 400 days.

Acknowledgements Open Access funding provided by Projekt DEAL. We thank K. Techmer for help with EBSD measurements and A. Kronz for guiding our electron microprobe analyses. B. Gordeychik is appreciated for his support in diffusion modeling and Smruti Rout for discussions. Two reviewers and suggestions by the CMP editor Othmar Müntener greatly improved this manuscript and their input is highly appreciated.

Funding This research was partially funded by funds of Geoscience Center (GZG) at the Georg-August Universität Göttingen.

\section{Compliance with ethical standards}

Conflict of interest The authors declare no conflicts of interest.
Open Access This article is licensed under a Creative Commons Attribution 4.0 International License, which permits use, sharing, adaptation, distribution and reproduction in any medium or format, as long as you give appropriate credit to the original author(s) and the source, provide a link to the Creative Commons licence, and indicate if changes were made. The images or other third party material in this article are included in the article's Creative Commons licence, unless indicated otherwise in a credit line to the material. If material is not included in the article's Creative Commons licence and your intended use is not permitted by statutory regulation or exceeds the permitted use, you will need to obtain permission directly from the copyright holder. To view a copy of this licence, visit http://creativecommons.org/licenses/by/4.0/.

\section{References}

Albert H, Costa F, Martí J (2015) Timing of magmatic processes and unrest associated with mafic historical monogenetic eruptions in Tenerife Island. J Petrol 56:1945-1966. https://doi.org/10.1093/ petrology/egv058

Albert H, Costa F, Martí J (2016) Years to weeks of seismic unrest and magmatic intrusions precede monogenetic eruptions. Geology 44:211-214. https://doi.org/10.1130/G37239.1

Albert H, Costa F, Di Muro A, Herrin J, Métrich N, Deloule E (2019) Magma interactions, crystal mush formation, timescales, and unrest during caldera collapse and lateral eruption at ocean island basaltic volcanoes (Piton de la Fournaise, La Réunion). Earth Planet Sci Lett 515:187-199. https://doi.org/10.1016/j. eps1.2019.02.035

Baales M, Jöris O, Street M, Bittmann F (2002) Impact of the late glacial eruption of Laacher See volcano, Central Rhineland, Germany. Quat Res 58(3):272-288. https://doi.org/10.1006/ qres.2002.2379

Bachmann O, Bergantz GW (2004) On the origin of crystal-poor rhyolites: extracted from batholithic crystal mushes. J Petrol 45(8):1565-1582. https://doi.org/10.1093/petrology/egh019

Bednarz U, Schmincke H-U (1990) Evolution of the Quaternary melilite-nephelinite Herchenberg volcano (East Eifel). Bull Volcanol $52: 426-444$

Berndt J, Holtz F, Koepke J (2001) Experimental constraints on storage conditions in the chemically zoned phonolitic magma chamber of the Laacher See volcano. Contrib Miner Petrol 140:469-486

Bourdon B, Zindler A, Wörner G (1994) Evolution of the Laacher See magma chamber: evidence from SIMS and TIMS measurements of U-Th disequilibria in minerals and glasses. Earth Planet Sci Lett 126:75-90

Bouvet de Maissonneuve C, Costa F, Huber C, Vonlanthen P, Bachmann O, Dungan MA (2016) How do olivines record magmatic events?. Contrib Miner Petrol, Insights from major and trace element zoning. https://doi.org/10.1007/s00410-016-1264-6

Bradshaw RW, Kent AJR, Tepley FJ III (2018) Chemical fingerprints and residence times of olivine in the 1959 Kilauea Iki eruption, Hawaii: insights into picrite formation. Am Miner 103(11):18121826. https://doi.org/10.2138/am-2018-6331

Brauer A, Endres C, Negendank JFW (1999) Lateglacial calendar year chronology based on annually laminated sediments from Lake Meerfelder Maar, Germany. Quatern Int 61(1):17-25. https://doi. org/10.1016/S1040-6182(99)00014-2

Brenna M, Cronin SJ, Smith IEM, Tollan PME, Scott LM, Prior DJ, Baambery K, Ukstins IA (2018) Olivine xenocrysts diffusion reveals rapid monogenetic basaltic magma ascent following complex storage at Pupuke Maar, Auckland Volcanic Field, New Zealand. Earth Planet Sci Lett 499:13-22. https://doi.org/10.1016/j. eps1.2018.07.015 
Bronk Ramsey C, Albert PA, Blockley SPE, Hardiman M, Housley RA, Lane CS, Lee S, Matthews IP, Smith VC, Lowe JJ (2015) Improved age estimates for key Late Quaternary European tephra horizons in the RESET lattice. Quat Sci Rev 118:18-32. https:// doi.org/10.1016/j.quascirev.2014.11.007

Caricchi L, Sheldrake TE, Blundy J (2018) Modulation of magmatic processes by CO2 flushing. Earth Planet Sci Lett 491:160-171

Carswell DA, Clarke DB, Mitchell RH (1979) The petrology and Geochemistry of Ultramafic Nodules from Pipe 200, Northern Lesotho. The Mantle Sample: Inclusion in Kimberlites and Other Volcanics. pp. 127-144

Cashman KV, Giordano G (2014) Calderas and magma reservoirs. J Volcanol Geotherm Res 288:28-45. https://doi.org/10.1016/j. jvolgeores.2014.09.007

Chakraborty S, Ganguly J (1991) Compositional zoning and cation diffusion in garnets. In: Ganguly J (ed) Diffusion, atomic ordering and mass transport. Advances in physical geochemistry. Vol 8, Springer, New York, pp 120-175

Coogan LA, Hain A, Stahl S, Chakraborty S (2005) Experimental determination of the diffusion coefficient for calcium in olivine between $900{ }^{\circ} \mathrm{C}$ and $1500{ }^{\circ} \mathrm{C}$. Geochim Cosmochim Acta 69:3683-3694. https://doi.org/10.1016/j.gca.2005.03.002

Coogan LA, Saunders AD, Wilson RN (2014) Aluminium-in-olivine thermometry of primitive basalts: evidence of an anomalously hot mantle source for large igneous provinces. Chem Geol 368:110. https://doi.org/10.1016/j.chemgeo.2014.01.004

Cooper KM, Kent AJR (2014) Rapid remobilization of magmatic crystals kept in cold storage. Nature 506(7489):480-483. https://doi. org/10.1038/nature12991

Cooper KM, Sims KWW, Eiler JM, Banerjee N (2016) Timescales of storage and recycling of crystal mush at Krafla Volcano, Iceland. Contrib Mineral Petrol 171(6):54. https://doi.org/10.1007/s0041 0-016-1267-3

Costa F, Chakraborty S (2004) Decadal time gaps between mafic intrusion and silicic eruption obtained from chemical zoning patterns in olivine. Earth Planet Sci Lett 227(3):517-530. https ://doi.org/10.1016/j.epsl.2004.08.011

Costa F, Dungan M (2005) Short time scales of magmatic assimilation from diffusion modeling of multiple elements in olivine. Geology 33(10):837-840. https://doi.org/10.1130/g21675.1

Costa F, Dohmen R, Chakraborty S (2008) Time scales of magmatic processes from modeling zoning patterns in crystals. Rev Miner Geochem 69(1):545-594. https://doi.org/10.2138/ rmg.2008.69.14

De Hoog JC, Gall L, Cornell DH (2010) Trace-element geochemistry of mantle olivine and application to mantle petrogenesis and geothermobarometry. Chem Geol 270:196-215

Denis CMM, Demouchy S, Shaw CSJ (2013) Evidence of dehydration in peridotites from the Eifel volcanic field and estimates on the rate of ascent. J Volcanol Geotherm Res 258:85-99. https://doi.org/10.1016/j.jvolgeores.2013.04.010

Dohmen R, Chakraborty S (2007) Fe-Mg diffusion in olivine II: point defect chemistry, change of diffusion mechanisms and a model for calculation of diffusion coefficients in natural olivine. Phys Chem Miner 34:409-430. https://doi.org/10.1007/ s00269-007-0158-6

Dohmen R, Becker H-W, Chakracorty (2003) Point defect equilibration and diffusion in olivine at low temperatures $\left(\mathrm{T}<1000^{\circ} \mathrm{C}\right)$. Eur J Mineral 15:42

Dohmen R, Becker H-W, Chakraborty S (2007) Fe-Mg diffusion coefficients in olivine. Part I: experimental determination between 700 and $1200{ }^{\circ} \mathrm{C}$ as a function of composition, crystal orientation and oxygen fugacity. Phys Chem Miner 34:389407. https://doi.org/10.1007/s00269-007-0157-7

Druitt TH, Costa F, Deloule E, Dungan M, Scaillet B (2012) Decadal to monthly timescales of magma transfer and reservoir growth at a caldera volcano. Nature 482:77-80. https://doi. org/10.1038/nature10706

Druitt TH, Mercier M, Florentin L, Deleoule E, Cluzel N, Flaherty T, Medard E, Cadoux A (2016) Magma storage and extraction associated with plinian and interplinian activity at Santorini caldera. J Pet 57(3):461-494. https://doi.org/10.1093/petro logy/egw015

Duda A, Schmincke H-U (1978) Quaternary basanites, melilite nephelinites and tephrites from the Laacher See area (Germany). N Jb Miner Abh 132(1):1-33

Duda A, Schmincke H-U (1985) Polybaric differentiation of alkali basaltic magmas: evidence from green-core clinopyroxenes (Eifel, FRG). Contrib Miner Petrol 91:340-353

Eichelberger JC, Izbekov PE, Browne BL (2006) Bulk chemical trends at arc volcanoes are not liquid lines of descent. Lithos 87(12):135-154. https://doi.org/10.1016/j.lithos.2005.05.006

Engels S, van Geel B, Buddelmeijer N, Brauer A (2015) High-resolution palynological evidence for vegetation response to the Laacher See eruption from the varved record of Meerfelder Maar (Germany) and other central European records. Rev Palaeobot Palyno 221:160-170. https://doi.org/10.1016/j.revpa lbo.2015.06.010

Fekiacova Z, Mertz DF, Renne P (2003) Geodynamic setting of the Hocheifel volcanism, western Germany. Geophys Res Abstr $5: 10355$

Folch A, Martí J (1998) The generation of overpressure in felsic magma chambers by replenishment. Earth Planet Sci Lett 163:301-314

Ginibre C, Wörner G, Kronz A (2004) Structure and dynamics of the Laacher See magma chamber (Eifel, Germany) from major and trace element zoning in sanidine: a cathodoluminescence and electron microprobe study. J Petrol 45(11):2197-2223. https:// doi.org/10.1093/petrology/egh053

Girona T, Costa F (2013) DIPRA: a user-friendly program to model multi-element diffusion in olivine with applications to timescales of magmatic processes. Geochem Geophys Geosyst 14(2):422431. https://doi.org/10.1029/2012GC004427

Gordeychik B, Churikova T, Kronz A, Sundermeyer C, Simakin A, Wörner G (2018) Growth of, and diffusion in, olivine in ultrafast ascending basalt magmas from Shiveluch volcano. Sci Rep 8(11775):1-15. https://doi.org/10.1038/s41598-018-30133-1

Harms E, Schmincke H-U (2000) Volatile composition of the phonolitic Laacher See magma (12,900 year BP): implications for syn-eruptive degassing of $\mathrm{S}, \mathrm{F}, \mathrm{Cl}$, and $\mathrm{H}_{2} \mathrm{O}$. Contrib Miner Petrol 138:84-98

Harms E, Gardner JE, Schmincke H-U (2004) Phase equilibria of the Lower Laacher See Tephra (East Eifel, germany): constraints on pre-eruptive storage conditions of a phonolitic magma reservoir. J Volcanol Geotherm Res 134(1-2):135-148

Hildreth W (1981) Gradients in silicic magma chambers: implications for lithospheric magmatism. J Geophys Res 86(B11):10153101902. https://doi.org/10.1029/JB086iB11p10153

Hildreth W, Wilson CJN (2007) Compositional zoning of the Bishop Tuff. J Petrol 48(5):951-999. https://doi.org/10.1093/petrology/ egm007

Jung C, Jung S, Hoffer E, Berndt J (2006) Petrogenesis of Tertiary mafic alkaline magmas in the Hocheifel, Germany. J Petrol 47(8):1637-1671. https://doi.org/10.1093/petrology/egl023

Kahl M, Chakraborty S, Costa F, Pompilio M (2011) Dynamic plumbing system beneath volcanoes revealed by kinetic modeling, and the connection to monitoring data: an example from Mt, Etna. Earth Planet Sci Lett 308(1):11-22. https://doi.org/10.1016/j. eps1.2011.05.008

Kahl M, Chakraborty S, Costa F, Pompilio M, Liuzzo M, Viccaro M (2013) Compositionally zoned crystals and real-time degassing data reveal changes in magma transfer dynamics during the 2006 
summit eruptive episodes of Mt, Etna. Bull Volcanol 75(2):692. https://doi.org/10.1007/s00445-013-0692-7

Kress V (1997) Magma mixing as a source for Pinatubo sulphur. Nature 389:591-593

Lane CS, Brauer A, Martín-Puertas C, Blockley SPE, Smith VC, Tomlinson EL (2015) The late Quaternary tephrostratigraphy of annually laminated sediments from Meerfelder Maar, Germany. Quat Sci Rev 122:192-206. https://doi.org/10.1016/j.quasc irev.2015.05.025

Lloyd FE (1987) Characterization of mantle metasomatic fluids in spinel lherzolites and alkali clinopyroxenites from the West Eifel and South West Uganda. In: Menzies M, Hawkesworth CJ (eds) Mantle metasomatism. Academic Press, London, pp 911-1023

Lynn KL, Shea T, Garcia MO (2017) Nickel variability in Hawaiian olivine: evaluating the relative contributions from mantle and crustal processes. Am Miner 102:507-518. https://doi.org/10.2138/ am-2017-5763

Lynn KL, Shea T, Garcia MO, Costa F, Norman MC (2018) Li diffusion in olivine records magmatic priming of explosive basaltic eruptions. Earth Planet Sci Lett 500:127-135. https://doi. org/10.1016/j.epsl.2018.08.002

Marsh BD (2006) Dynamics of magmatic systems. Elements 2:287292. https://doi.org/10.2113/gselements.2.5.287

Mertes H (1983) Aufbau und Genese des Westeifeler Vulkanfeldes. Bochumer Geol und Geotechn Arb 9:1-415

Mertes H, Schmincke H-U (1985) Mafic potassic lavas of the Quaternary West Eifel volcanic field. Contrib Miner Petrol 89:330-345

Michon L, Merle O (2001) The evolution of the massif Central rift: spatio-temporal distribution of the volcanism. Bulletin de la Société Géologique de France 172:201-211

Milman-Barris MS, Beckett JR, Baker MB, Hofmann AE, Morgan Z, Crowley MR, Vielzeuf D, Stolper E (2008) Zoning of phosphorous in igneous olivine. Contrib Miner Petrol 155(6):739-765. https://doi.org/10.1007/s00410-007-0268-7

Murphy MD, Sparks RSJ, Barclay J, Carroll MR, Brewer TS (2000) Remobilization of andesite magma by intrusion of mafic magma at the Soufriere Hills Volcano, Montserrat, West Indies. J Petrol 41(1):21-42

Mutch EJF, Maclennan J, Shorttle O, Edmonds M, Rudge JF (2019) Rapid transcrustal magma movement under Iceland. Nat Geosci 12:569-574. https://doi.org/10.1038/s41561-019-0376-9

Nakamura M (1995) Residence times and crystallization history of nickeliferous olivine phenocrysts from the northern Yatsugatake volcanoes, Central Japan: application of a growth and diffusion model in the system Mg-Fe-Ni. J Volcanol Geotherm Res 66:81-100

Nowell DAG, Jones MC, Pyle DM (2006) Episodic Quaternary volcanism in France and Germany. J Quat Sci 21(6):645-675. https://doi.org/10.1002/jqs.1005

Pallister JS, Hoblitt RP, Reyes AG (1992) A basalt trigger for the 1991 eruptions of Pinatubo volcano? Nature 356:426-428

Park C, Schmincke H-U (1997) Lake formation and catastrophic dam burst during the Late Pleistocene Laacher See eruption (Germany). Naturwissenschaften 84:521-525

Park C, Schmincke H-U (2020) Multistage damming of the Rhine River by tephra fallout during the 12,900 BP Plinian Laacher See Eruption (Germany). Syn-eruptive Rhine damming I. J Volcanol Geotherm Res 389:106688. https://doi.org/10.1016/j. jvolgeores.2019.106688

Petrone CM, Bugatti G, Braschi E, Tommasini S (2016) Pre-eruptive magmatic processes re-timed using a non-isothermal approach to magma chamber dynamics. Nat Commun 7:12946. https:// doi.org/10.1038/ncomms 12946

Petry C, Chakraborty S, Palme H (2004) Experimental determination of Ni diffusion coefficients in olivine and their dependence on temperature, composition, oxygen fugacity, and crystallographic orientation. Geochim Cosmochim Acta 68:4179-4188. https://doi.org/10.1016/j.gca.2004.02.024

Prior DJ, Boyle AP, Brenker F, Cheadle MC, Day A, Lopez G, Peruzzi L, Potts G, Reddy S, Spiess R, Timms NE, Trimby P, Wheeler J, Zetterstrom L (1999) The application of electron backscatter diffraction and orientation contrast imaging in the SEM to textural problems in rocks. Am Mineral 84(1112):1741-1759. https://doi.org/10.2138/am-1999-11-1204

Rasmussen DJ, Plank TA, Roman DC, Power JA, Bodnar RJ, Hauri EH (2018) When does the eruption run-up begin? Multidisciplinary insight from the 1999 eruption at Shishaldin volcano. Earth Planet Sci Lett 486:1-14. https://doi.org/10.1016/j. eps1.2018.01.001

Ritter JRR, Jordan M, Christensen UR, Achauer U (2001) A mantle plume below the Eifel volcanic fields, Germany. Earth Planet Sci Lett 186:7-14

Rout SS, Wörner G (2018) Zoning and exsolution in alkali feldspars from Laacher See volcano (Western Germany): constraints on temperature history prior to eruption. Contrib Miner Petrol 173:95. https://doi.org/10.1007/s00410-018-1522-x

Rout SS, Wörner G (2020) Constraints on the pre-eruptive magmatic history of Laacher See volcano (Germany). Contrib Mineral Petrol 175:73. https://doi.org/10.1007/s00410-020-01710-3

Rout SS, Schmidt B, Wörner G (2020) Constraints on non-isothermal diffusion modeling: an experimental analysis and error assessment using halogen diffusion in melts. Am Mineral 105(2):227-238. https://doi.org/10.2138/am-2020-7193

Rubin AE, Cooper KM, Till CB et al (2017) Rapid cooling and cold storage in a silicic magma reservoir recorded in individual crystals. Science 356:1154-1156

Ruprecht P, Plank T (2013) Feeding andesitic eruptions with a highspeed connection from the mantle. Nature 500:68-72. https:// doi.org/10.1038/nature 12342

Schmincke H-U (1977) Eifel Vulkanismus östlich des Gebietes Rieden-Mayen. Fortschr Mineral 55(2):1-32

Schmincke H-U (2007) The Quaternary Volcanic Fields of the East and West Eifel (Germany). In: Ritter JRR, Christensen UR (eds) Mantle plumes. Springer, Berlin

Schmincke H-U, Park C, Harms E (1999) Evolution and environmental impacts of the eruption of Laacher See volcano (Germany) 12,900 a BP. Quat Int 61:61-72

Schmitt AK (2006) Laacher See revisited: high-spatial-resolution zircon dating indicates rapid formation of a zoned magma chamber. Geology 34(7):597-600. https://doi.org/10.1130/G22533.1

Schmitt AK, Wetzel F, Cooper KM, Zou H, Wörner G (2010) Magmatic Longevity of Laacher See Volcano (Eifel, Germany) Indicated by U-Th Dating of Intrusive Carbonatites. J Petrol 51(5):1053-1085. https://doi.org/10.1093/petrology/egq011

Shaw CSJ (2004) The temporal evolution of three magmatic systems in the West Eifel volcanic field, Germany. J Volcano Geotherm Res 131:213-240

Shaw CSJ, Klügel A (2002) The pressure and temperature conditions and timing of glass formation in mantle-derived xenoliths from Baarley, West Eifel, Germany: the case for amphibole breakdown, lava infiltration and mineral-melt reaction. Miner Petrol 74:163-187

Shaw CSJ, Lebert BS, Woodland AB (2018) Thermodynamic modelling of mantle-melt interaction evidences by the veined wehrlite xenoliths from the Rockeskyllerkopf volcanic complex, West Eifel volcanic field, Germany. J Petrol 59(1):59-86. https://doi. org/10.1093/petrology/egy018

Shea T, Lynn KL, Garcia MO (2015) Cracking the olivine zoning code: distinguishing between crystal growth and diffusion. Geology 43(10):935-938. https://doi.org/10.1130/G37082.1 
Simon NS, Carlson RW, Pearson DG, Davies GR (2007) The origin and evolution of the Kaapvaal cratonic lithospheric mantle. J Petrol 48:589-625

Snyder D (2000) Thermal effects of the intrusion of basaltic magma into a more silicic magma chamber and implications for eruption triggering. Earth Planet Sci Lett 175:257-273

Sparks SRJ, Sigurdsson H, Wilson L (1977) Magma mixing: a mechanism for triggering acid explosive eruptions. Nature 267:315-318

Sundermeyer C, Di Muro A, Gordeychik B, Wörner G (2020) Timescales of magmatic processes during the eruptive cycle 20142015 at Pion de la Fournaise, La Réunion, obtained from Mg-Fe diffusion modelling in olivine. Contrib Mineral Petrol. https:// doi.org/10.1007/s00410-019-1642-y

Tait SR, Wörner G, van den Bogaard P, Schmincke H-U (1989) Cumulate nodules as evidence for convective fractionation in a phonolite magma chamber. J Volcanol Geotherm Res 37:21-37

Ubide T, Kamber BS (2018) Volcanic crystals as time capsules of eruption history. Nat Commun 9(326):1-12. https://doi.org/10.1038/ s41467-017-02274-w

van den Bogaard P (1995) 40Ar/39Ar ages of sanidine phenocrysts from Laacher See Tephra (12,900 yr BP): chronostratigraphic and petrological significance. Earth Planet Sci Lett 133:163-174

van den Bogaard P, Schmincke H-U (1984) The eruptive center of the late Quaternary Laacher See tephra. Geol Rundsch 73(3):933-980

van den Bogaard P, Schmincke H-U (1985) Laacher See Tephra: a widespread isochronous late Quaternary tephra layer in central and northern Europe. GSA Bull 96(12):1554-1571. https://doi. org/10.1130/0016-7606(1985)96\%3c1554:LSTAWI\%3e2.0.CO;2

Viccaro M, Giuffrida M, Nicotra E, Cristofolini R (2016) Timescales of magma storage and migration recorded by olivine crystals in basalts of the March-April 2010 eruption at Eyjafjallajökull volcano, Iceland. Am Mineral 101(1):222-230. https://doi. org/10.2138/am-2016-5365

Wark DA, Hildreth W, Spear FS, Cherniak DJ, Watson EB (2007) Pre-eruptive recharge of the Bishop magma system. Geology 35(3):235-238. https://doi.org/10.1130/G23316A.1

Watson EB, Cherniak DJ, Holycross ME (2015) Diffusion of phosphorous in olivine and molten basalt. Am Mineral 100(10):20532065. https://doi.org/10.2138/am-2015-5416
Wiebe RA (2016) Mafic replenishments into floored silicic magma chambers. Am Mineral 101(2):297-310. https://doi.org/10.2138/ am-2016-5429

Witt-Eickschen G, Klemd R, Seck HA (2003) Density contrast of fluid inclusions associated with melt (glass) from two distinct suites of mantle peridotites from the West Eifel, Germany: implications for melt origin. Eur J Miner 15(1):95-102

Wolff JA, Ellis BS, Ramos FC et al (2015) Remelting of cumulates as a process for producing chemical zoning in silicic tuffs: a comparison of cool, wet and hot, dry rhyolitic magma systems. Lithos 236-237:275-286. https://doi.org/10.1016/j.lithos.2015.09.002

Wörner G (1982) Geochemisch-mineralogische Entwicklung der Laacher See Magmakammer. Ph.D. thesis, Ruhr Universität Bochum

Wörner G, Schmincke H-U (1984a) Mineralogical and chemical zonation of the Laacher See tephra sequence (East Eifel, W. Germany). J Petrol 25(4):805-835

Wörner G, Schmincke H-U (1984b) Petrogenesis of the zoned Laacher See tephra. J Petrol 25(4):836-885

Wörner G, Wright TL (1984) Evidence for magma mixing within the Laacher See magma chamber (East Eifel, Germany). J Volcanol Geotherm Res 22:301-327

Wörner G, Staudigel H, Zindler A (1985) Isotopic constraints on open system evolution of the Laacher See magma chamber (Eifel, West Germany). Earth Planet Sci Lett 75:37-49

Wörner G, Viereck L, Plaumann S, Pucher R, van den Bogaard P, Schmincke H-U (1988) The Quaternary Wehr volcano: a multiphase evolved eruption center in the east Eifel volcanic field (FRG). N Jb Miner Abh 159(1):73-99

Wright HMN, Folkes CB, Cas RAF, Cashman KV (2011) Heterogeneous pumice populations in the 2.08-MA Cerro Galán ignimbrite: implications for magma recharge and ascent preceding a largevolume silicic eruption. Bull Volcanol 73:1513-1533. https://doi. org/10.1007/s00445-011-0525-5

Publisher's Note Springer Nature remains neutral with regard to jurisdictional claims in published maps and institutional affiliations. 